\title{
39. RARE EARTH, MAJOR, AND TRACE ELEMENT COMPOSITION OF LEG 127 SEDIMENTS ${ }^{1}$
}

\author{
Richard W. Murray, ${ }^{2}$ Marilyn R. Buchholtz ten Brink, ${ }^{3}$ Hans-J. Brumsack, ${ }^{4}$ David C. Gerlach, ${ }^{5}$ and G. Price Russ III ${ }^{5}$
}

\begin{abstract}
The relative effects of paleoceanographic and paleogeographic variations, sediment lithology, and diagenetic processes on the final preserved chemistry of Japan Sea sediments are evaluated by investigating the rare earth element (REE), major element, and trace element concentrations in 59 squeeze-cake whole-round and 27 physical-property sample residues from Sites 794, 795, and 797, cored during ODP Leg 127.

The most important variation in sedimentary chemical composition is the increase in $\mathrm{SiO}_{2}$ concentration through the Pliocene diatomaceous sequences, which dilutes most other major and trace element components by various degrees. This biogenic input is largest at Site 794 (Yamato Basin), moderately developed at Site 797 (Yamato Basin), and of only minor importance at Site 795 (Japan Basin), potentially reflecting basinal contrasts in productivity with the Yamato Basin recording greater biogenic input than the Japan Basin and with the easternmost sequence of Site 794 lying beneath the most productive waters. There are few systematic changes in solid-phase chemistry resulting from the opal-A/opal-CT or opal-CT/quartz silica phase transformations. Most major and trace element concentrations are controlled by the aluminosilicate fraction of the sediment, although the effects of diagenetic silica phases and manganese carbonates are of localized importance.

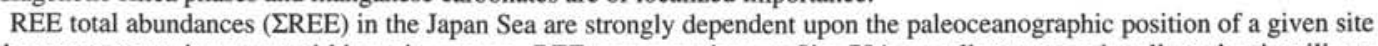
with respect to terrigenous and biogenic sources. REE concentrations at Site 794 overall correspond well to aluminosilicate chemical indices and are strongly diluted by $\mathrm{SiO}_{2}$ within the upper Miocene-Pliocene diatomaceous sequence. Eu/Eu* values at Site 794 reach a maximum through the diatomaceous interval as well, most likely suggesting an association of Eu/Eu* with the siliceous component, or reflecting slight incorporation of a detrital feldspar phase. ¿REE at Site 795 also is affiliated strongly with aluminosilicate phases and yet is diluted only slightly by siliceous input. At Site 797, 2 REE is not as clearly associated with the aluminosilicate fraction, is correlated moderately to siliceous input, and may be sporadically influenced by detrital heavy minerals originating from the nearby rifted continental fragment composing the Yamato Rise.

$\mathrm{Ce} / \mathrm{Ce}^{*}$ profiles at all three sites increase essentially monotonically with depth and record progressive diagenetic LREE fractionation. The observed $\mathrm{Ce} / \mathrm{Ce}^{*}$ increases are not responding to changes in the paleoceanographic oxygenation state of the overlying water, as there is no independent evidence to suggest the proper oceanographic conditions. $\mathrm{Ce} / \mathrm{Ce}$ * correlates slightly better with depth than with age at the two Yamato Basin sites.

The downhole increase in Ce/Ce* at Sites 794 and 797 is a passive response to the diagenetic transfer of LREE (except Ce) from sediment to interstitial water. At Site 795 , the overall lack of correlation between $\mathrm{Ce} / \mathrm{Ce} *$ and $\mathrm{La}_{\mathrm{n}} / \mathrm{Yb}_{\mathrm{n}}$ suggests that other processes mask the diagenetic behavior of all LREEs. First-order calculations of the Ce budget in Japan Sea waters and sediment indicate that $\sim 20 \%$ of the excess Ce adsorbed by settling particles is recycled within the water column and that an additional $\sim 38 \%$ is recycled at or near the seafloor. Thus, because the remaining excess $\mathrm{Ce}$ is only $\sim 10 \%$ of the total $\mathrm{Ce}$, there is not a large source of $\mathrm{Ce}$ to the deeply buried sediment, further suggesting that the downhole increase in $\mathrm{Ce} / \mathrm{Ce} *$ is a passive response to diagenetic behavior of the other LREEs. The REE chemistry of Japan Sea sediment therefore predicts successive downhole addition of LREEs to deeply buried interstitial waters.
\end{abstract}

\section{INTRODUCTION}

The chemical composition of sediments from a marginal ocean basin records the geologic history of the basin and the source terrane(s) from a different perspective than the physical record provided by the sediments themselves. Subtle changes in the redox state of the overlying water, for example, may be recognizable only in the chemical distributions within the sediment column. Variations in the composition of the sedimentary source and in the depositional position of the sediment with respect to metalliferous and terrigenous inputs also affect the chemical composition of sediment. When a sedimentary

${ }^{1}$ Pisciotto, K. A., Ingle, J. C., Jr., von Breymann, M. T., Barron, J., et al., 1992. Proc. ODP, Sci. Results, 127/128, Pt. 1: College Station, TX (Ocean Drilling Program).

2 Department of Geology and Geophysics, University of California at Berkeley, Berkeley, CA 94720, U.S.A. (Present address: Graduate School of Oceanography, University of Rhode Island, Narragansett, RI 02882, U.S.A.

${ }^{3}$ Earth Sciences Department, Lawrence Livermore National Laboratory, Livermore, CA 94550 , U.S.A.

${ }^{4}$ Geochemisches Institut, Goldschmidtstr. 1, D-3400, Gottingen, Federal Republic of Germany.

${ }^{5}$ Nuclear Chemistry Division, Lawrence Livermore National Laboratory, Livermore, CA 94550, U.S.A. (Gerlach, present address: Charles Evans and Associates, 301 Chesapeake Drive, Redwood City, CA 94063, U.S.A.; Russ, present address: Chemistry and Material Sciences Department, Lawrence Livermore National Laboratory, Livermore, CA 94550, U.S.A. grain settles onto the basin floor, however, diagenetic processes begin to modify its chemistry, and the preserved signals of the sedimentary basin's history may change with time. The degree of change will depend on the susceptibility of the element(s) in question to mobilize under diagenetic conditions. In many cases the diagenetic reactions within the sediments provide important information regarding the basin's geologic history.

The sedimentary sequences in the Japan Sea present a terrific opportunity to assess both the chemical sources to fine-grained sediments and the post-depositional diagenetic processes that modify the sediment's primary chemical composition. The Japan Sea is a small, enclosed, marginal ocean basin in which the sedimentary sources and depositional regimes are well characterized by lithostratigraphic sequences recording $2000-5000 \mathrm{~m}$ of deposition (Fig. 1). Further resolution of the depositional environments is provided by the wealth of sedimentologic, biostratigraphic, and chemical data collected during Ocean Drilling Program (ODP) Legs 127 and 128. As such, the physical stratigraphic framework is constructed within which chemical variations may be placed. Moreover, Japan Sea sediments are currently undergoing many different stages of diagenesis, including sulfate reduction, silica phase transformations, and carbonate dissolution/recrystallization (Murray et al., this volume), and changes in sediment chemistry may potentially be tied to these diagenetic processes. In particular, the siliceous sequence provides an advantage 


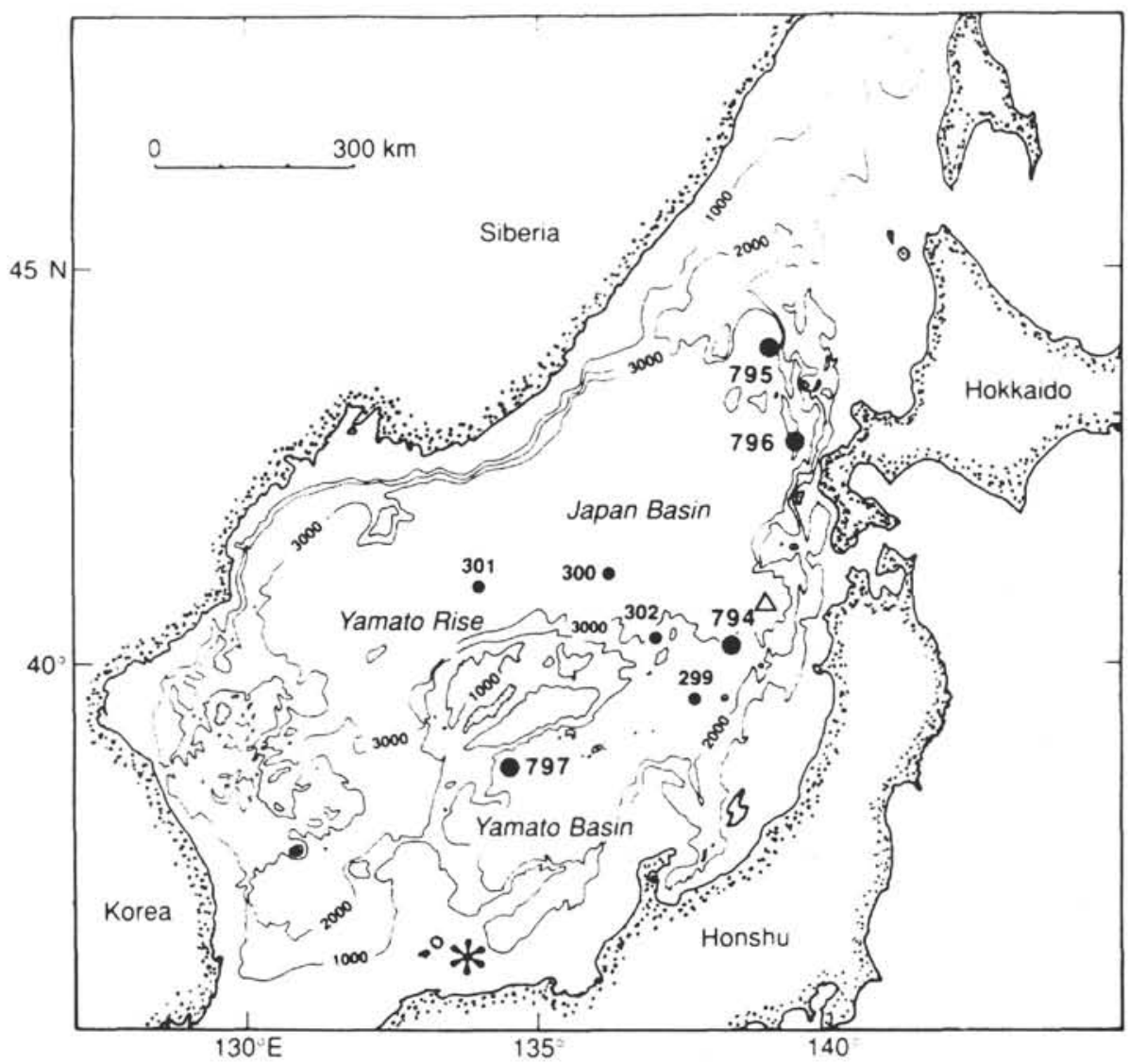

Figure 1. Location map of the Japan Sea showing locations of Leg 127 Sites 794-797 and Deep Sea Drilling Project Leg 31 Sites 299-302. Bathymetry contoured in meters. a marks the approximate position of the study of REEs in settling particles near Site $794\left(40.8^{\circ} \mathrm{N}, 138.7^{\circ} \mathrm{E}\right.$; Masuzawa and Koyama, 1989); * marks the approximate position of the study of REEs in Japan Sea water $\left(35.7^{\circ} \mathrm{N}, 133.2^{\circ} \mathrm{E}\right.$; Tanaka et al., 1990). Map modified from Tamaki, Pisciotto, Allan, et al., 1990.

when addressing large-scale diagenetic changes, as the diagenetic state of the sample can be tracked easily by the $\mathrm{SiO}_{2}$ phases as they progress through the successive opal-A/opal-CT/quartz diagenetic transitions.

This study attempts to resolve the lithologic and diagenetic parameters that control the chemical composition of Japan Sea sediments. Superimposed on both these effects are paleoceanographic changes that have potentially modified the chemistry of Japan Sea sediments through time. While paleoceanographic variations and paleogeographic location each in turn influence sediment lithology and diagenetic conditions through a given stratigraphic sequence, we restrict our definition of paleoceanographic variations to include those large-scale changes in seawater composition that will substantially influence the rare earth element (REE) record in sediment throughout both Japan Sea basins. By tracking chemical behavior across lithologic, diagenetic, and paleoceanographic boundaries, we address the relative importance of each potential influence under a variety of sedimentologic regimes.

\section{Paleoceanographic Evolution of the Japan Sea}

In order to place the chemical variations of the different lithologies of sediments preserved in the Japan and Yamato basins within the proper stratigraphic context, the general paleoceanographic history of the Japan Sea relevant to our chemical investigation is summarized here. Comprehensive presentations of the lithostratigraphic and paleoceanographic changes are presented elsewhere in great detail (Tamaki, Pisciotto, Allan, et al., 1990; plus papers in this volume).
The preliminary paleoceanographic dates and sedimentation rates described herein and used throughout this paper are based on descriptions in Tamaki, Pisciotto, Allan, et al. (1990); more recent values presented in other papers in this volume supersede those used here.

Initial extension and rifting began in the Japan Sea in the early(?) Miocene to early middle Miocene and resulted in the gravity-flow deposition of volcaniclastic sandstones and siltstones along the basin margin. Accelerated deepening of the Yamato Basin during the early Miocene and of the Japan Basin during the early middle Miocene is characterized by fine-grained, diatomaceous and calcareous clay-rich pelagic and hemipelagic muds. Bottom-water (500-1500 m) conditions were most likely oxic to dysaerobic throughout the entire Miocene, as indicated by foraminifer assemblages and bioturbation/lamination character. The three sites $(794,795$, and 797$)$ for which chemistry is reported here were either bathymetrically isolated or too distal from terrigenous inputs during this time to receive coarse clastic deposits. Site 797 (Yamato Basin) may have been slightly deeper than Sites 794 and 795. From the late Miocene to the Pliocene, an increase in diatom productivity resulted in hemipelagic diatomaceous and siliceous sedimentation. Bottom waters (1500-2500 m) were generally oxygenated and intrabasin circulation was well developed, although communication between the Yamato and Japan basins may have been restricted during the middle late Miocene. After these highly productive conditions, bathyal hemipelagic muds were deposited from the Pliocene to the present. Sea-level fluctuations may have also affected terrigenous inputs and resulted in periods of anoxic deep water. Within the Quaternary section, preservation of dark-light cycles in silty clays may record fluctuations of terrigenous input, oxy- 
genation level, type of organic matter, surface-water productivity, or sedimentation rate. These dark-light cycles are described extensively elsewhere in this volume.

\section{Composite Lithostratigraphic Succession}

The lithostratigraphic sequences that result from this paleoceanographic evolution are relatively similar at all three sites studied here (Fig. 2); details of the lithologic successions, terminology usage, and criteria used to divide lithologic units are discussed elsewhere (Tamaki, Pisciotto, Allan, et al., 1990). Silica phase transformations have a profound affect on sedimentary lithology at each site and are located on all chemical profiles. A composite downhole lithostratigraphic sequence is described in the following, with key differences among sites highlighted. Note that the unit numbers do not correlate among the sites (Fig. 2).

The uppermost $\sim 100 \mathrm{~m}$ below seafloor (mbsf) consists generally of slightly to highly bioturbated gray clay, silty ashy clay, and diatomaceous clay, which were deposited through the late Pliocene and Quaternary. Discrete ash beds (1-5 cm thick) are a volumetrically minor yet numerous component. Dark-light cycles tend to be more notable in the uppermost tens of meters. Minor calcareous layers (including diagenetic dolomite or ankerite, and manganese carbonates) are found throughout. Diatom abundances decrease toward the base of Unit I at Site 795 and increase toward the base of Unit I at Site 797. Beneath this sequence are moderately to intensely bioturbated diatom and clayey diatom ooze. The age and duration of deposition of this sequence is different from site to site (Fig. 2). Ash beds ( $1-5 \mathrm{~cm}$ thick) are sparsely disseminated and very rare. Minor dolomicrite and dolomitic nodules also occur, usually within concentrations of foraminifers. At Site 794, the lowermost portion of this diatomaceous sequence (Subunit IIB) consists of diatom clay similar to the purer diatom ooze except with less diatoms. Below the diatom ooze is a middle to upper Miocene sequence consisting of moderately to intensely bioturbated diatomaceous clay and faintly laminated siliceous claystone, along with dolomite layers, pyrite, and ash interspersed throughout. Dolomite, ankerite, and silica cements are present locally in small nodules, stringers, lenses and laminae, as are porcellanite and chert layers. The poor recovery through this section at Site 795 may indicate a greater abundance of chert layers than was observed in the recovered samples. Thin carbonate layers are relatively common at Site 797. Beneath the siliceous claystone at Site 794 are moderately bioturbated claystone, silty claystone, and calcareous claystone, with an increasing diagenetic dolomite and ankerite component.

\section{ANALYTICAL METHODOLOGY}

\section{Sample Preparation}

Most samples in this study are splits of the whole-round squeezecake residues from the nylon- and Teflon-lined interstitial-water squeezer described by Brumsack et al. (this volume). The samples were analyzed for their major element, trace element, and REE composition as described in the following. Not every squeeze cake was prepared for geochemical analysis, but the continuity of the

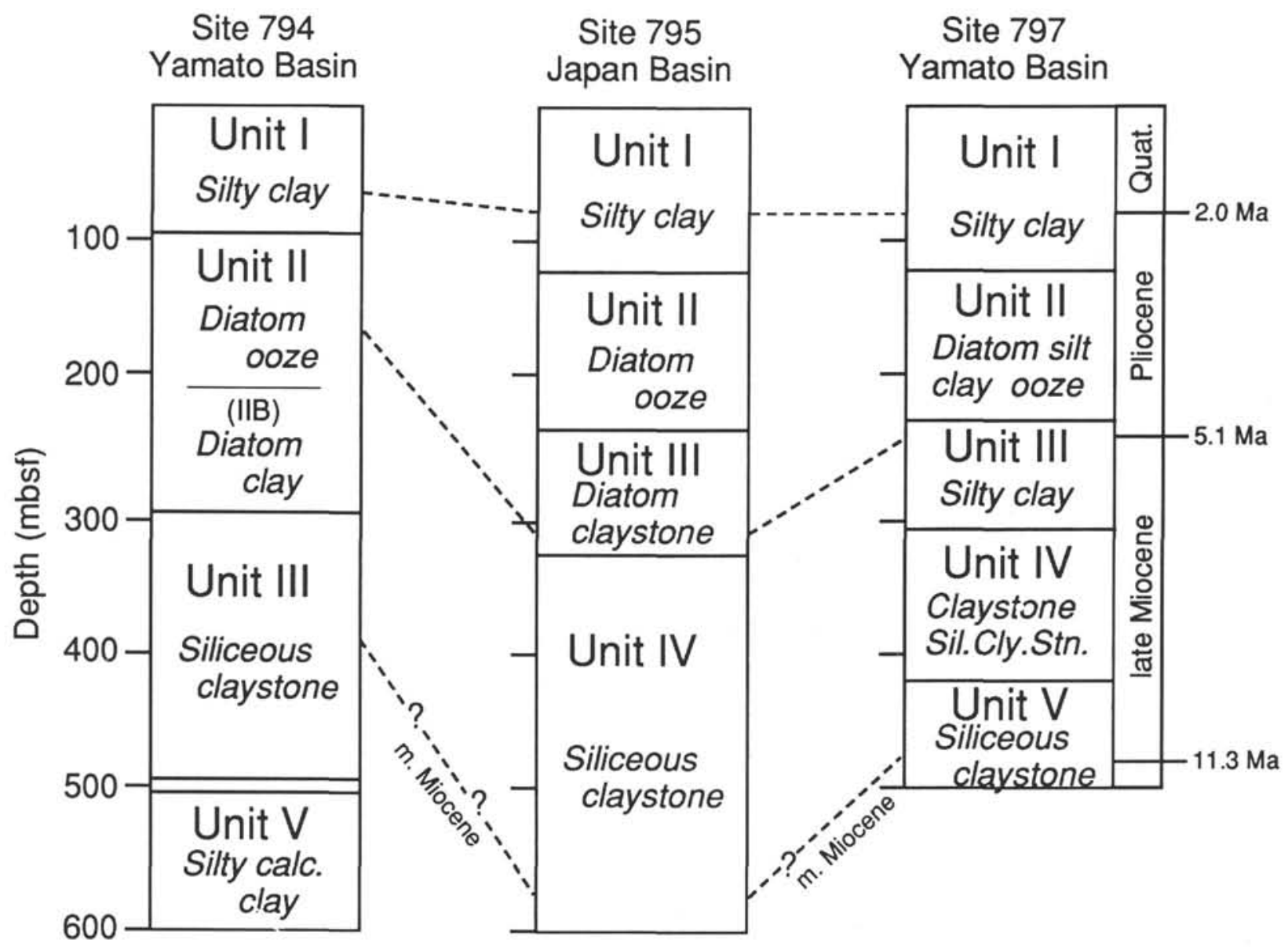

Figure 2. Lithostratigraphic summary of Leg 127 sites analyzed for sedimentary chemistry. Note that the unit numbers do not correlate among the sites. Unit IV at Site 794 was not sampled in this study. 
Table 1. Major element data ( $w t \%$, volatile free) from Leg 127 squeeze-cake residues and physical-property samples.

\begin{tabular}{|c|c|c|c|c|c|c|c|c|c|c|c|c|}
\hline $\begin{array}{l}\text { Core, section, } \\
\text { interval }(\mathrm{cm})\end{array}$ & $\begin{array}{l}\text { Depth } \\
\text { (mbsf) }\end{array}$ & Subunit & $\mathrm{SiO}_{2}$ & $\mathrm{Al}_{2} \mathrm{O}_{3}$ & $\mathrm{CaO}$ & $\mathrm{MgO}$ & $\mathrm{Na}_{2} \mathrm{O}$ & $\mathrm{K}_{2} \mathrm{O}$ & $\mathrm{Fe}_{2} \mathrm{O}_{3}$ & $\mathrm{MnO}$ & $\mathrm{TiO}_{2}$ & $\mathrm{P}_{2} \mathrm{O}_{5}$ \\
\hline \multicolumn{13}{|l|}{$127-794 \mathrm{~A}-$} \\
\hline $1 \mathrm{H}-3,140-145$ & 4.4 & IA & 62.0 & 17.7 & 1.01 & 3.25 & 3.74 & 3.53 & 7.87 & 0.15 & 0.71 & 0.13 \\
\hline $3 \mathrm{H}-5,140-145$ & 23.7 & IA & 64.3 & 17.9 & 1.71 & 2.99 & 2.74 & 3.62 & 5.84 & 0.10 & 0.70 & 0.12 \\
\hline $6 \mathrm{H}-4,145-150$ & 50.8 & IA & 62.7 & 15.5 & 0.71 & 3.41 & 2.82 & 3.33 & 10.4 & 0.24 & 0.76 & 0.11 \\
\hline $9 \mathrm{H}-4,145-150$ & 79.3 & IB & 66.9 & 16.3 & 0.71 & 2.99 & 2.80 & 3.52 & 5.86 & 0.18 & 0.69 & 0.08 \\
\hline $12 \mathrm{H}-4,145-150$ & 107.8 & IIA & 70.2 & 14.0 & 0.73 & 2.79 & 3.01 & 2.90 & 5.39 & 0.37 & 0.58 & 0.08 \\
\hline $15 \mathrm{H}-4,145-150$ & 136.3 & IIA & 79.2 & 9.29 & 0.45 & 2.04 & 2.60 & 2.02 & 3.77 & 0.17 & 0.39 & 0.06 \\
\hline $22 \times-4,145-150$ & 203.5 & IIA & 80.8 & 8.60 & 0.48 & 2.20 & 2.17 & 1.70 & 3.42 & 0.21 & 0.35 & 0.05 \\
\hline $25 X-4,145-150$ & 232.5 & IIB & 71.6 & 11.0 & 1.11 & 4.14 & 2.49 & 2.24 & 5.09 & 1.83 & 0.44 & 0.07 \\
\hline $29 X-4,145-150$ & 271.4 & IIB & 65.3 & 15.2 & 0.68 & 4.74 & 3.06 & 3.07 & 6.79 & 0.49 & 0.61 & 0.08 \\
\hline $33 \mathrm{X}-2,140-145$ & 309.2 & IIIA & 67.3 & 15.0 & 0.63 & 4.13 & 2.14 & 3.42 & 6.30 & 0.39 & 0.61 & 0.10 \\
\hline $36 \mathrm{X}-4,145-150$ & 337.9 & IIIA & 66.5 & 15.3 & 0.67 & 4.52 & 2.50 & 3.41 & 5.71 & 0.72 & 0.58 & 0.07 \\
\hline \multicolumn{13}{|l|}{$127-794 \mathrm{~B}-$} \\
\hline $12 \mathrm{R}-1,145-150$ & 406.4 & IIIB & 79.9 & 9.16 & 2.17 & 1.98 & 1.41 & 1.72 & 3.18 & 0.08 & 0.36 & 0.06 \\
\hline $18 R-4,145-150$ & 468.5 & IIIB & 74.3 & 11.1 & 0.43 & 4.76 & 1.45 & 2.98 & 4.33 & 0.13 & 0.42 & 0.08 \\
\hline $24 \mathrm{R}-2,140-145$ & 523.7 & V & 64.3 & 12.6 & 2.42 & 4.88 & 1.61 & 4.19 & 6.62 & 2.75 & 0.48 & 0.15 \\
\hline \multicolumn{13}{|l|}{$127-795 \mathrm{~A}-$} \\
\hline $1 \mathrm{H}-4,145-150$ & 6.0 & IA & 64.1 & 17.2 & 1.27 & 3.07 & 2.79 & 3.36 & 7.03 & 0.39 & 0.73 & 0.14 \\
\hline $2 \mathrm{H}-4,145-150$ & 15.3 & LA & 64.5 & 17.2 & 1.08 & 3.15 & 2.54 & 3.56 & 6.92 & 0.15 & 0.75 & 0.13 \\
\hline $3 \mathrm{H}-4,145-150$ & 24.8 & IA & 64.6 & 15.1 & 1.08 & 3.37 & 2.95 & 3.10 & 8.58 & 0.51 & 0.59 & 0.11 \\
\hline $4 \mathrm{H}-4,145-150$ & 34.8 & IA & 62.3 & 17.0 & 1.20 & 3.01 & 2.64 & 3.21 & 9.62 & 0.21 & 0.71 & 0.14 \\
\hline $5 \mathrm{H}-4,145-150$ & 43.8 & IA & 66.1 & 15.8 & 1.50 & 2.35 & 3.68 & 3.41 & 6.37 & 0.18 & 0.59 & 0.10 \\
\hline $6 \mathrm{H}-4,145-150$ & 53.8 & IA & 66.9 & 15.3 & 1.15 & 2.85 & 3.02 & 2.99 & 7.00 & 0.12 & 0.63 & 0.12 \\
\hline $7 \mathrm{H}-4,145-150$ & 62.8 & IA & 65.8 & 17.0 & 1.01 & 3.09 & 3.12 & 3.27 & 5.71 & 0.24 & 0.72 & 0.11 \\
\hline $8 \mathrm{H}-4,145-150$ & 72.3 & IA & 63.3 & 16.9 & 1.06 & 3.07 & 2.98 & 3.22 & 7.85 & 0.73 & 0.73 & 0.11 \\
\hline $9 \mathrm{H}-4,145-150$ & 81.8 & IA & 64.5 & 16.4 & 0.86 & 3.15 & 2.99 & 3.30 & 7.85 & 0.17 & 0.71 & 0.10 \\
\hline $10 \mathrm{H}-1,145-150$ & 86.8 & IB & 65.4 & 17.2 & 0.93 & 3.05 & 2.82 & 3.42 & 6.09 & 0.11 & 0.75 & 0.12 \\
\hline $12 \mathrm{H}-4,140-145$ & 110.2 & IB & 67.7 & 14.6 & 1.16 & 2.97 & 2.87 & 2.81 & 7.00 & 0.24 & 0.61 & 0.10 \\
\hline $15 \mathrm{H}-4,140-145$ & 138.7 & II & 70.9 & 13.2 & 0.83 & 2.88 & 2.48 & 2.52 & 6.45 & 0.09 & 0.55 & 0.08 \\
\hline $18 \mathrm{H}-4,140-145$ & 158.8 & II & 71.4 & 13.3 & 1.06 & 2.51 & 2.62 & 2.48 & 5.84 & 0.10 & 0.55 & 0.08 \\
\hline $21 X-4,140-145$ & 187.5 & II & 77.3 & 10.8 & 0.72 & 2.02 & 2.40 & 2.07 & 4.11 & 0.09 & 0.47 & 0.07 \\
\hline $25 X-3,140-145$ & 224.8 & II & 71.4 & 13.1 & 0.89 & 2.83 & 2.57 & 2.53 & 5.87 & 0.16 & 0.58 & 0.08 \\
\hline $29 X-2,140-145$ & 262.4 & IIIA & 74.6 & 11.8 & 1.09 & 2.35 & 2.58 & 2.08 & 4.84 & 0.09 & 0.52 & 0.07 \\
\hline $30 \times-2,145-150$ & 272.3 & IIIA & 73.3 & 11.9 & 0.93 & 2.48 & 2.55 & 2.23 & 5.79 & 0.10 & 0.62 & 0.09 \\
\hline $31 X-4,145-150$ & 285.1 & IIIA & 75.2 & 11.3 & 0.98 & 2.12 & 2.49 & 2.07 & 5.12 & 0.09 & 0.57 & 0.08 \\
\hline${ }^{3} 34 X-1,100-102$ & 308.9 & IIIB & 73.9 & 11.1 & 0.95 & 2.22 & 3.82 & 2.20 & 5.13 & 0.09 & 0.55 & 0.08 \\
\hline $34 \mathrm{X}-3,100-102$ & 311.9 & IIIB & 72.4 & 12.2 & 1.00 & 2.58 & 3.27 & 2.29 & 5.36 & 0.09 & 0.63 & 0.09 \\
\hline $34 X-4,100-102$ & 313.4 & IIIB & 75.5 & 11.7 & 0.98 & 2.61 & 2.51 & 2.00 & 4.03 & 0.08 & 0.53 & 0.07 \\
\hline $34 X-5,140-145$ & 315.3 & IIIB & 74.0 & 12.3 & 0.88 & 2.39 & 2.75 & 2.27 & 4.75 & 0.08 & 0.57 & 0.08 \\
\hline $34 \mathrm{X}-6,100-102$ & 316.4 & IIIB & 75.3 & 12.1 & 0.84 & 2.80 & 2.41 & 1.95 & 3.90 & 0.08 & 0.56 & 0.06 \\
\hline${ }^{3} 34 X-7,39-40$ & 317.3 & IIIB & 74.7 & 11.6 & 1.10 & 1.84 & 3.46 & 2.42 & 4.25 & 0.08 & 0.50 & 0.08 \\
\hline $35 X-1,100-102$ & 318.6 & IIIB & 74.8 & 11.0 & 0.81 & 2.30 & 3.46 & 2.18 & 4.77 & 0.08 & 0.54 & 0.07 \\
\hline $35 X-2,145-150$ & 320.6 & IIIB & 76.3 & 11.3 & 0.72 & 2.17 & 2.36 & 1.93 & 4.58 & 0.08 & 0.54 & 0.08 \\
\hline $35 X-3,100-102$ & 321.6 & IIIB & 77.0 & 10.3 & 0.86 & 2.01 & 2.95 & 1.91 & 4.29 & 0.07 & 0.51 & 0.08 \\
\hline $35 X-4,100-102$ & 323.1 & IIIB & 73.4 & 12.1 & 0.96 & 2.44 & 2.89 & 2.19 & 5.26 & 0.08 & 0.61 & 0.09 \\
\hline${ }^{2} 35 X-6,100-102$ & 326.1 & IIIB & 70.2 & 13.5 & 0.98 & 2.70 & 3.04 & 2.50 & 6.15 & 0.08 & 0.69 & 0.09 \\
\hline${ }^{3} 37 \mathrm{X}-1,99-100$ & 337.9 & IVA & 80.5 & 9.1 & 0.62 & 1.68 & 2.14 & 1.69 & 3.73 & 0.05 & 0.46 & 0.07 \\
\hline $37 X-1,145-150$ & 338.4 & IVA & 76.9 & 10.8 & 0.66 & 2.02 & 2.37 & 2.02 & 4.51 & 0.07 & 0.51 & 0.07 \\
\hline
\end{tabular}

profiles was assured. Samples were split aboard JOIDES Resolution by cutting with a knife down the longitudinal axis of the compressed cake. An additional suite of physical-property residue samples from Sites 795 and 797 were split aboard the ship and analyzed for major and trace elements (no REE) as described in the following. On shore, after oven-drying at $\sim 150^{\circ} \mathrm{C}$ for $3-5 \mathrm{hr}$, all samples were powdered by hand in an agate mortar and pestle.

\section{Analytical Procedure and Uncertainty}

Approximately $20 \mathrm{~g}$ of squeeze-cake residue was powdered and split for REE and major/trace element analysis. Major and trace elements were analyzed by X-ray fluorescence (XRF) at X-Ray Assay Laboratories, Don Mills, Ontario, Canada. REEs were analyzed by ICP-mass spectrometry (ICP-MS) at Lawrence Livermore National Laboratory. Complete sample dissolution prior to introduction into the ICP-MS was achieved by $\mathrm{HNO}_{3}-\mathrm{HF}-\mathrm{HClO}_{4}$ microwave digestion in sealed Teflon beakers, as detailed elsewhere (Murray et al., 1991). Samples were prepared and run in random order (i.e., mixed sites and depths) on different analytical runs, days, and ICP-MS instruments. Values of Ba determined from XRF were used to correct for ionization suppression of REEs (average $~ 30 \%$ ) during ICP-MS analysis; the accuracy for REEs therefore is as good as the Ba XRF values $(5 \%-\leq 10 \%)$. Replicate analyses of solutions indicate that the precision of the Ba ionization correction is $\pm 4 \%$ for light REEs (LREEs; La to Nd) and $\pm 8 \%$ for heavy REEs (HREEs; Er to Lu), even though the \% suppression is nonreproducible and may vary between runs of the same solution on different days by $10 \%-20 \%$. As determined by replicate analyses of USGS reference rocks MAG-1, SCo-1, and SGr-1 (Taylor and McLennan, 1985; Jarvis and Jarvis, 1985), the general precision of the ICP-MS analysis is $\sim 55 \%$ for LREEs and $5 \%-10 \%$ for HREEs (Murray et al., 1991). Gd is systematically higher $(18 \%)$ in the reference rocks, which is most likely due to interferences on ${ }^{157} \mathrm{Gd}$ from ${ }^{138} \mathrm{BaF}^{+}$or ${ }^{140} \mathrm{CeOH}^{++}$(Murray et al., 
Table 1 (continued).

\begin{tabular}{|c|c|c|c|c|c|c|c|c|c|c|c|c|}
\hline $\begin{array}{l}\text { Core, section, } \\
\text { interval }(\mathrm{cm})\end{array}$ & $\begin{array}{l}\text { Depth } \\
\text { (mbsf) }\end{array}$ & Subunit & $\mathrm{SiO}_{2}$ & $\mathrm{Al}_{2} \mathrm{O}_{3}$ & $\mathrm{CaO}$ & $\mathrm{MgO}$ & $\mathrm{Na}_{2} \mathrm{O}$ & $\mathrm{K}_{2} \mathrm{O}$ & $\mathrm{Fe}_{2} \mathrm{O}_{3}$ & $\mathrm{MnO}$ & $\mathrm{TiO}_{2}$ & $\mathrm{P}_{2} \mathrm{O}_{5}$ \\
\hline \multicolumn{13}{|l|}{ 127-795B- } \\
\hline IR-1, 140-145 & 366.6 & IVA & 67.3 & 15.2 & 0.84 & 2.67 & 2.38 & 2.97 & 7.84 & 0.08 & 0.68 & 0.10 \\
\hline $9 \mathrm{R}-2,111-113$ & 445.0 & IVB & 88.1 & 5.7 & 0.38 & 0.90 & 1.17 & 1.15 & 2.26 & 0.03 & 0.27 & 0.04 \\
\hline a $11 \mathrm{R}-3,81-83$ & 464.0 & IVB & 72.5 & 13.8 & 0.84 & 2.27 & 1.96 & 2.56 & 5.28 & 0.08 & 0.58 & 0.07 \\
\hline "12R-3, 96-98 & 475.4 & IVB & 73.4 & 13.5 & 0.76 & 2.15 & 1.82 & 2.64 & 5.03 & 0.08 & 0.57 & 0.07 \\
\hline $13 R-2,140-145$ & 483.9 & IVB & 70.9 & 14.5 & 0.96 & 2.21 & 1.97 & 2.73 & 6.08 & 0.07 & 0.64 & 0.07 \\
\hline${ }^{\mathrm{a}} 13 \mathrm{R}-3,63-65$ & 484.6 & IVB & 72.2 & 14.1 & 0.70 & 2.16 & 1.95 & 2.71 & 5.39 & 0.07 & 0.58 & 0.06 \\
\hline${ }^{\mathrm{a}} 14 \mathrm{R}-3,127-129$ & 495.0 & IVB & 63.4 & 19.0 & 2.07 & 2.36 & 2.31 & 1.81 & 8.21 & 0.06 & 0.63 & 0.14 \\
\hline $19 \mathrm{R}-1,140-145$ & 540.1 & IVB & 79.0 & 11.2 & 0.64 & 1.58 & 1.33 & 2.11 & 3.69 & 0.03 & 0.46 & 0.05 \\
\hline \multicolumn{13}{|l|}{$127-796 \mathrm{~A}-$} \\
\hline $2 \mathrm{H}-4,145-150$ & 9.2 & IA & 65.3 & 17.2 & 1.89 & 2.75 & 3.00 & 2.87 & 6.09 & 0.09 & 0.70 & 0.14 \\
\hline $5 \mathrm{H}-5,145-150$ & 39.2 & IA & 62.1 & 15.6 & 6.62 & 2.47 & 2.64 & 2.95 & 6.81 & 0.11 & 0.64 & 0.13 \\
\hline $9 X-2,145-150$ & 61.8 & IB & 67.1 & 16.0 & 1.61 & 2.54 & 2.80 & 2.90 & 6.20 & 0.17 & 0.67 & 0.10 \\
\hline $11 X-1,145-150$ & 79.8 & IB & 67.6 & 15.9 & 1.74 & 2.55 & 2.97 & 2.68 & 5.66 & 0.10 & 0.70 & 0.10 \\
\hline \multicolumn{13}{|l|}{$127-797 \mathrm{~B}-$} \\
\hline IH-2, 145-150 & 3.0 & IA & 62.6 & 17.3 & 1.19 & 3.28 & 2.65 & 3.68 & 8.30 & 0.09 & 0.74 & 0.15 \\
\hline $2 \mathrm{H}-4,145-150$ & 11.9 & IA & 60.5 & 17.3 & 1.31 & 2.93 & 2.74 & 3.43 & 10.8 & 0.11 & 0.77 & 0.16 \\
\hline $3 \mathrm{H}-5,140-145$ & 22.8 & IA & 65.0 & 18.0 & 0.76 & 3.13 & 2.37 & 3.78 & 5.85 & 0.09 & 0.83 & 0.14 \\
\hline $4 \mathrm{H}-4,145-150$ & 30.9 & IA & 57.6 & 16.4 & 9.62 & 3.30 & 2.20 & 3.29 & 6.47 & 0.33 & 0.71 & 0.13 \\
\hline $5 \mathrm{H}-4,145-150$ & 40.4 & IA & 62.5 & 17.8 & 1.01 & 3.06 & 3.00 & 3.71 & 7.81 & 0.35 & 0.71 & 0.12 \\
\hline $6 \mathrm{H}-4,140-145$ & 49.8 & IA & 65.1 & 17.7 & 0.71 & 2.87 & 2.74 & 3.45 & 6.41 & 0.28 & 0.66 & 0.10 \\
\hline $7 \mathrm{H}-4,145-150$ & 59.4 & IA & 65.0 & 17.4 & 0.81 & 3.25 & 2.51 & 3.66 & 6.33 & 0.23 & 0.70 & 0.11 \\
\hline $8 \mathrm{H}-4,145-150$ & 68.9 & IA & 67.4 & 16.1 & 0.74 & 2.82 & 2.59 & 3.17 & 6.12 & 0.30 & 0.64 & 0.09 \\
\hline $9 \mathrm{H}-4,140-145$ & 78.3 & IA & 64.9 & 17.8 & 0.96 & 2.08 & 3.71 & 4.14 & 5.48 & 0.15 & 0.66 & 0.12 \\
\hline $10 \mathrm{H}-4,145-150$ & 87.9 & IB & 66.6 & 16.0 & 0.60 & 3.27 & 2.47 & 3.36 & 6.67 & 0.18 & 0.72 & 0.09 \\
\hline $12 \mathrm{H}-4,145-150$ & 106.9 & IB & 66.9 & 15.9 & 1.03 & 1.93 & 3.88 & 4.02 & 4.98 & 0.88 & 0.52 & 0.09 \\
\hline $15 \mathrm{H}-4,145-150$ & 135.4 & II & 64.1 & 17.2 & 0.58 & 3.64 & 2.68 & 3.37 & 7.21 & 0.43 & 0.69 & 0.09 \\
\hline $18 \mathrm{H}-4,145-150$ & 163.9 & II & 59.8 & 9.93 & 5.47 & 3.30 & 1.70 & 2.05 & 4.28 & 12.9 & 0.37 & 0.17 \\
\hline $21 X-4,140-145$ & 191.4 & II & 75.1 & 12.1 & 0.39 & 2.71 & 2.05 & 2.39 & 4.56 & 0.20 & 0.52 & 0.07 \\
\hline $24 X-5,140-145$ & 221.7 & II & 75.3 & 11.1 & 0.43 & 2.75 & 2.05 & 2.19 & 5.27 & 0.28 & 0.52 & 0.08 \\
\hline $27 X-6,140-145$ & 252.3 & III & 69.3 & 14.4 & 0.57 & 3.53 & 2.51 & 2.62 & 6.03 & 0.26 & 0.59 & 0.08 \\
\hline $28 \mathrm{X}-1,145-150$ & 254.6 & III & 67.1 & 14.6 & 0.68 & 4.37 & 2.54 & 2.74 & 6.81 & 0.35 & 0.70 & 0.10 \\
\hline $30 X-1,99-101$ & 273.5 & III & 63.2 & 15.7 & 0.91 & 4.43 & 4.23 & 2.96 & 7.38 & 0.29 & 0.74 & 0.12 \\
\hline $30 X-1,145-150$ & 274.0 & III & 68.6 & 14.5 & 1.04 & 3.65 & 2.40 & 2.59 & 6.20 & 0.25 & 0.65 & 0.14 \\
\hline $31 X-2,98-100$ & 284.7 & III & 69.1 & 13.0 & 1.01 & 3.38 & 4.02 & 2.28 & 6.39 & 0.21 & 0.58 & 0.13 \\
\hline $31 X-5,96-98$ & 289.2 & III & 64.2 & 15.4 & 1.17 & 4.48 & 3.47 & 3.00 & 6.82 & 0.55 & 0.76 & 0.14 \\
\hline $32 X-2,98-100$ & 294.4 & III & 65.0 & 15.1 & 1.25 & 4.06 & 3.87 & 2.63 & 6.85 & 0.26 & 0.72 & 0.20 \\
\hline $32 X-3,145-150$ & 296.4 & III & 65.8 & 16.2 & 0.94 & 4.10 & 2.65 & 2.86 & 6.44 & 0.24 & 0.69 & 0.14 \\
\hline $32 X-5,99-100$ & 298.9 & III & 65.2 & 15.4 & 0.81 & 4.19 & 3.17 & 2.93 & 7.16 & 0.23 & 0.71 & 0.12 \\
\hline $33 X-1,100-101$ & 302.5 & IVA & 63.8 & 15.8 & 0.89 & 4.58 & 3.09 & 3.05 & 7.55 & 0.31 & 0.75 & 0.11 \\
\hline $33 X-2,145-150$ & 304.5 & IVA & 64.1 & 16.7 & 0.69 & 4.36 & 2.72 & 3.29 & 7.04 & 0.32 & 0.70 & 0.10 \\
\hline${ }^{2} 33 X-3,100-101$ & 305.5 & IVA & 63.6 & 16.7 & 0.97 & 3.82 & 3.05 & 3.39 & 7.37 & 0.24 & 0.74 & 0.14 \\
\hline $34 X-2,145-150$ & 314.2 & IVA & 62.9 & 17.5 & 0.94 & 3.87 & 2.48 & 3.93 & 6.83 & 0.81 & 0.72 & 0.13 \\
\hline $42 X-1,47-49$ & 388.4 & IVB & 82.9 & 7.3 & 0.36 & 2.08 & 1.50 & 1.56 & 3.78 & 0.11 & 0.32 & 0.08 \\
\hline $44 X-1,29-31$ & 407.6 & IVB & 88.4 & 5.2 & 0.34 & 1.75 & 1.24 & 1.06 & 1.58 & 0.06 & 0.24 & 0.06 \\
\hline $46 X-1,40-42$ & 427.0 & $\mathrm{~V}$ & 84.5 & 6.9 & 0.42 & 1.93 & 1.56 & 1.54 & 2.73 & 0.08 & 0.31 & 0.08 \\
\hline $47 X-1,107-109$ & 437.3 & V & 75.3 & 11.8 & 0.52 & 3.39 & 1.74 & 2.62 & 3.94 & 0.12 & 0.45 & 0.08 \\
\hline${ }^{a} 48 X-1,100-102$ & 446.9 & V & 81.9 & 7.5 & 0.45 & 3.61 & 1.43 & 1.72 & 2.96 & 0.13 & 0.31 & 0.07 \\
\hline
\end{tabular}

Note: Analyses by XRF at X-Ray Assay Laboratories, Don Mills, Ontario, Canada.

${ }^{\text {a }}$ Physical-property residue sample.

1991), although visual inspection of shale-normalized plots of data from this study do not show a systematic Gd enrichment. Final LREE concentrations agree well $( \pm 4 \%$ ) with previous studies of other Japan Sea sediments determined by instrumental neutron activation analysis (Masuzawa and Koyama, 1989); HREE data are difficult to compare as a result of the non-shalelike $\mathrm{Tb}, \mathrm{Yb}$, and $\mathrm{Lu}$ ratios presented in the data table of Masuzawa and Koyama (1989), as well as the lack of HREE agreement between their table and shale-normalized REE plot.

\section{REE Terminology}

REE abundances in marine sediments commonly are normalized to average shale values to minimize the effect of the odd-even variability in elemental abundances. Normalization values used here (Table 1) are an average of North American, European, and Russian shale composites used by previous workers; note that $\mathrm{Tb}$ values from this composite are probably too high, causing an apparent Tb depletion in the shale-normalized REE plot (Murray et al., 1991). Tm and Lu values may also be high (R. L. Korotev, pers. comm., 1991). Nevertheless, we use these values because they are widely used by marine chemists (see discussion in Sholkovitz, 1988) and are therefore of most use for comparing results between studies of ocean waters and marine sediment. Moreover, use of the North American Shale Composite (NASC) for ICP-MS REE data is handicapped because not all HREEs in NASC are analyzed by a common technique (Gromet et al., 1984). Shale values used here for normalization purposes do not necessarily represent the average REE terrigenous input pattern (Sholkovitz, 1988, 1990; Condie, 1991). We calculate the $\mathrm{Ce}$ anomaly using the ratio $\mathrm{Ce} / \mathrm{Ce} *=\left(\mathrm{Ce}_{\text {sample }} / \mathrm{Ce}_{\text {shale }}\right) / \mathrm{Ce} *$, where $\mathrm{Ce}^{*}$ is the predicted value obtained by linear interpolation between 
shale-normalized $\mathrm{La}$ and $\operatorname{Pr}$ values. The Eu anomaly (Eu/Eu*) is calculated similarly, using values of shale-normalized Sm and Gd. $\mathrm{Ce} / \mathrm{Ce} *$ and/or $\mathrm{Eu} / \mathrm{Eu} * \sim 1$ does not imply flatness across any portion of the shale-normalized REE spectrum, including the $\mathrm{Ce}$ and $\mathrm{Eu}$ regions. Precision of $\mathrm{Ce} / \mathrm{Ce} *$ and $\mathrm{Eu} / \mathrm{Eu}^{*}$ is estimated to be $\sim 5 \%$, with accuracy estimated at $\sim \leq 10 \%$ for $\mathrm{Ce} / \mathrm{Ce} *$ and higher for $\mathrm{Eu} / \mathrm{Eu} *$ because of potential interferences on $\mathrm{Gd}(\leq 15 \%$, see previous discussion). Contrasts in LREE vs. HREE behavior are quantified by the ratio $\mathrm{La}_{\mathrm{n}} / \mathrm{Yb}_{\mathrm{n}}=\left(\mathrm{La}_{\text {sample }} / \mathrm{La}_{\text {shale }}\right) /\left(\mathrm{Yb}_{\text {sample }} / \mathrm{Yb}_{\text {shale }}\right)$.

\section{RESULTS AND DISCUSSION}

Major element (volatile free), REE, and trace element data for all Leg 127 sites are reported in Tables 1 and 2, and the respective concentration profiles are also presented for Sites 794, 795, and 797 (Figs. 3 through 5). Concentration data from Site 796 are presented in Tables 1 and 2 but are not discussed, as only four samples were analyzed. Correlation coefficient values $(r)$ between various elements at each site are listed in Tables 3 through 5; except where noted, listed values are for correlations through the entire sequence and may mask local associations not visible at discrete intervals. Throughout the discussion, we often reference data to $\mathrm{Al}$ because it is primarily from a terrigenous source and can therefore be used to monitor varying terrestrial inputs and because $\mathrm{Al}$ is relatively insoluble and immobile during diagenesis (e.g., Hower et al., 1976; Boles and Franks, 1979). Results are presented here on a site-by-site basis in order to synthesize the different styles of chemical behavior responding to the lithologic and diagenetic influences through a common stratigraphy. Site 794 is discussed in the greatest detail, as many of the aspects of chemical behavior at Site 794 are observed at Sites 795 and 797 and need not be repeated. The site presentations are followed by discussion of the REE compositions of Japan Sea sediments and their implications for the sedimentary history of the Japan Sea.

The downhole profiles of the raw concentration data allow assessment of the broad associations of particular elements to different lithologies. For example, as will be shown in the following, $\mathrm{SiO}_{2}$ concentrations are commonly associated with diatomaceous sequences. The $\mathrm{Al}$-normalized profiles show how an element's concentration changes with respect to terrigenous input. If a given $\mathrm{Al}$-normalized profile records elemental behavior that cannot be related to the inferred terrigenous or siliceous inputs, then the element must be responding to a third parameter, for example, phosphate. In all profiles, significant deviations $( \pm 15 \%)$ from the average, especially if part of a larger trend, may be interpretable in the context of stratigraphic heterogeneity controlled by local parameters. In some cases, comparison between different profiles on a point-by-point basis elucidates the causes behind the perturbations. In other cases, however, sharp and isolated increases or decreases in concentration are not associated between elements at the same site, which limits successful interpretation.

\section{Site 794}

\section{Major Elements}

The most important variation in major element concentrations at Site 794 is the varying $\mathrm{SiO}_{2}$ concentration, which dilutes concentrations of the other major elements to different degrees (Fig. 3A and Table 3). This is seen clearly, for example, through the diatom ooze and diatomaceous clay of Unit II, where $\mathrm{SiO}_{2}$ concentrations reach a maximum of $80.8 \mathrm{wt} \%$ in Subunit IIA, before decreasing through the siliceous clays of Subunit IIB. $\mathrm{SiO}_{2}$ concentrations remain essentially constant at $\sim 66 \mathrm{wt} \%$ through the opal-A/opal-CT diagenetic transition. The elevated $\mathrm{SiO}_{2}$ values below the opal-CT/quartz transition within Subunit IIIB may reflect the increasing amount of silica cements, stringers, and lenses in Subunit IIIB (Tamaki, Pisciotto, Allan, et al., 1990). Within the claystones of Unit V, $\mathrm{SiO}_{2}$ concentrations return to average shale values.
In addition to the expected $\mathrm{Si} / \mathrm{Al}$ increase, the $\mathrm{Na} / \mathrm{Al}$ ratio also increases through Unit II (Fig. 3B). This profile may reflect a strong affiliation of $\mathrm{Na}$ with the biogenic opal or an affiliated clay phase, with $\mathrm{Na}$ being adsorbed from either interstitial waters or seawater, as suggested by Donnelly and Merrill (1977), or perhaps may record an inherited chemical signature from detrital inputs (e.g., plagioclase feldspar) that are not uniform through time. We will discuss these and other potential causes further, in the context of the $\mathrm{Eu} / \mathrm{Eu}^{*}$ data.

Other Al-normalized major element profiles show downhole variation at Site 794 (Fig. 3B). K/Al, Fe/Al, Mn/Al, Ca/Al (excepting one point), $\mathrm{Mg} / \mathrm{Al}$, and $\mathrm{P} / \mathrm{Al}$ increase from Unit III to Unit $\mathrm{V}$, the same interval through which $\mathrm{Si} / \mathrm{Al}$ decreases, implying response to the concentration of the siliceous component. Alternatively, these increases may reflect the diagenetic formation of carbonate/phosphate within and below Unit III. Fe/Al also shows a relative maximum within the diatom clay of Subunit IIB. The overall slight $\mathrm{Mg} / \mathrm{Al}$ increase from the seafloor through the diatomaceous ooze of Subunit IIA is consistent with an additional Mg component potentially recording adsorption onto biogenic opal (e.g., Donnelly and Merrill, 1977).

\section{Rare Earth Elements}

The REEs are affected by increases and decreases in the biogenic $\mathrm{SiO}_{2}$ component at Site 794 , as shown by $r=-0.93$ between $\Sigma$ REE and $\mathrm{SiO}_{2}$ (Table 6) and visually apparent from the pronounced $\Sigma$ REE minima through the siliceous Subunit IIA and $\Sigma$ REE increases from Unit III to Unit V (Fig. 4 and Table 2). RREE/Al values are essentially constant through Unit II, indicating an association of REEs with aluminosilicate phases. This is also suggested by high $r$ values between $\Sigma$ REE and $\mathrm{Al}_{2} \mathrm{O}_{3}, \mathrm{TiO}_{2}, \mathrm{~K}_{2} \mathrm{O}, \mathrm{Fe}_{2} \mathrm{O}_{3}$, and $\mathrm{P}_{2} \mathrm{O}_{5}$, which tend to be present in shalelike relative abundances (e.g., Gromet et al., 1984). As such, all may be responding to the $\mathrm{SiO}_{2}$ dilution.

$\mathrm{Ce} / \mathrm{Ce}^{*}$ values are all positive and increase consistently from values of $\sim 1.08$ for shallow samples to a maximum of $\mathrm{Ce} / \mathrm{Ce}^{*}=1.61$ within the siliceous claystone of Subunit IIIA (Fig. 4). The near-surface values are consistent with the $\mathrm{Ce} / \mathrm{Ce} *$ value $\sim 1.07$ reported by Masuzawa and Koyama (1989) from surficial sediment 50-100 km north of Site 794 (Fig. 1). There is no change in trend through the diatomaceous interval of Unit II, nor is there a change in value across the opal-A/opal-CT diagenetic transition. $\mathrm{Ce} / \mathrm{Ce} *$ decreases sharply to $\mathrm{Ce} / \mathrm{Ce}^{*}=1.15$, however, across the opal-CT/quartz transition between Subunits IIIA and IIIB. As discussed previously, $\mathrm{SiO}_{2}$ concentrations tend to increase through this interval as well, which suggests that the $\mathrm{Ce} / \mathrm{Ce}^{*}$ decrease is a diagenetic change, with the newly precipitating biogenic quartz phases recording a lower $\mathrm{Ce} / \mathrm{Ce} *$ value than the primary sediment. The relatively high $r$ value between $\mathrm{Ce} / \mathrm{Ce}^{*}$ and $\mathrm{MnO}(0.81$; Table 6) suggests that the excess $\mathrm{Ce}$ is associated with $\mathrm{Mn}$.

$\mathrm{Eu} / \mathrm{Eu} *$ varies only slightly through the sedimentary column, averaging $1.03 \pm 0.05$, except for a large and systematic increase within the diatom ooze of Unit II, where Eu/Eu* peaks at 1.28 (Fig. 4). The correlation coefficient of $r=0.69$ between Eu/Eu* and $\mathrm{SiO}_{2}$ suggests that $\mathrm{Eu} / \mathrm{Eu} *$ is affiliated with the biogenic siliceous component, which is controlling the negative $r$ values between $\mathrm{Eu} / \mathrm{Eu} *$ and the remaining elements (Table 6). There is essentially no change in Eu/Eu* across either the opal-A/opal-CT or opal-CT/quartz diagenetic boundary. The single high Eu/Eu* point in Unit III corresponds with large decreases in $\mathrm{CaO}$ and $\mathrm{Sr}$ and with an increase in $\mathrm{La}_{\mathrm{n}} / \mathrm{Yb}_{\mathrm{n}}$; no other major or trace elements deviate significantly in that sample from the overall trend.

Shale-normalized Eu anomalies have been reported only from marine waters affected by aeolian input $\left(\mathrm{Eu} / \mathrm{Eu}^{*}<1\right)$ or hydrothermal input (Eu/Eu* $>1$; Elderfield, 1988). Neither of these potential inputs can be responsible for the observed positive Eu anomalies through the diatomaceous Unit II sequence as (1) the Eu anomaly peak at Site 794 is positive, not negative, and (2) there clearly is no independent 
evidence of hydrothermal input into the sequences (e.g., metalliferous sediment or $\mathrm{Ce} / \mathrm{Ce} *<1$, and $\mathrm{Fe}_{2} \mathrm{O}_{3}$ averages a low $5.75 \pm 1.90$ ). $\mathrm{Eu} / \mathrm{Eu}^{*}$ is not likely to respond to diagenetic influences within the sediment column (see discussion in McLennan, 1989). The relationship between $\mathrm{Eu} / \mathrm{Eu}^{*}$ and $\mathrm{SiO}_{2}$ implies that the siliceous component is carrying a slightly positive Eu anomaly, although this would require Eu fractionation during construction of diatom tests or during adsorption from seawater and/or incorporation of a Eu-enriched phase into or onto diatom tests. A slight relative increase in the primary detrital feldspar component could also cause an inherited positive Eu/Eu* anomaly in the bulk sediment, even if the feldspars have been diagenetically altered, due to the high $\mathrm{Eu} / \mathrm{Eu} *$ of plagioclase and alkali feldspars (e.g., Eu/Eu* 7-40; Dymek and Gromet, 1984; Taylor and McLennan, 1985). The coincidence of the peaks in Eu/Eu* and $\mathrm{Na} / \mathrm{Al}$ may also be consistent with the presence of a detrital feldspar component in this interval, although the small feldspar component implied by the slight bulk $\mathrm{Eu} / \mathrm{Eu}^{*}$ increase (from $\sim 1$ to $\sim 1.3$ ) relative to feldspar Eu/Eu* ( 7-40, as noted previously) may not supply sufficient $\mathrm{Na}$ to generate the $\mathrm{Na} / \mathrm{Al}$ increase. Although the fact that the $\mathrm{Eu}$ enrichment occurs only at Site 794 (where the biogenic input is most pronounced) argues for a siliceous influence, we cannot rigorously resolve these potential mechanisms given the current data base, and we hope that additional information about this interval will be gained from mineralogical studies at this site (e.g., Fagel et al., 1991).

$\mathrm{La}_{\mathrm{n}} / \mathrm{Yb}_{\mathrm{n}}$ values, which indicate the relative behavior of LREEs to HREEs, remain in the range $\sim 0.97$ to $\sim 1.34$ through Units I and II (Fig. 4), only slightly less than the estimated average terrigenous input of $\mathrm{La}_{\mathrm{n}} / \mathrm{Yb}_{\mathrm{n}}$ of $\sim 1.3$ suggested by Sholkovitz (1990) and generally agreeing with the value of $\sim 1$ suggested by Condie (1991). Within the diatomaceous ooze of Subunit IIA, $\mathrm{La}_{n} / \mathrm{Yb}_{\mathrm{n}}$ values reach a relative minimum of 0.97 and increase through the diatomaceous clay of Subunit IIB to $\mathrm{La}_{\mathrm{n}} / \mathrm{Yb}_{\mathrm{n}}=1.34$. Below Unit II, $\mathrm{La}_{\mathrm{n}} / \mathrm{Yb}_{\mathrm{n}}$ values show more scatter, yet on average are lower in the siliceous claystones of Unit III and the silty calcareous clay of Unit V. The low $\mathrm{La}_{\mathrm{n}} / \mathrm{Yb}_{\mathrm{n}}$ value of 0.69 is coincident with high $\mathrm{CaO}$ and $\mathrm{Ca} / \mathrm{Al}$. The potential for a causal link between the changes in $\mathrm{La}_{\mathrm{n}} / \mathrm{Yb}_{\mathrm{n}}$ and $\mathrm{Ce} / \mathrm{Ce}$ * below the opal-A/opal-CT transition at Site 794 will be addressed later.

\section{Trace Elements}

$\mathrm{Cr}, \mathrm{Rb}, \mathrm{Y}, \mathrm{Zr}$, and $\mathrm{Nb}$ concentrations all have similar downhole profiles that decrease through Subunit IIA (Fig. 5A); concentrations also correlate negatively with the $\mathrm{SiO}_{2}$ concentration (Table 3) indicating that these elements are not associated with the biogenic sedimentary component. $\mathrm{Ba}$ is enriched slightly through Subunit IIA, although $\mathrm{Sr}$ values are within the same range as $\mathrm{Sr}$ values in the silty clays and siliceous claystones above and below the interval.

The essentially constant $\mathrm{Al}$-normalized profiles of $\mathrm{Rb}, \mathrm{Zr}$, and $\mathrm{Nb}$ (Fig. 5B) further suggest that these elements are affiliated predominantly with the aluminosilicate phase. Most $r$ values of the trace elements are greatest with $\mathrm{Al}_{2} \mathrm{O}_{3}$ and $\mathrm{TiO}_{2}$ (Table 3). Of these elements, however, $\mathrm{Y} / \mathrm{Al}$ is enriched in the clay-rich diatomaceous Subunit IIB, and $\mathrm{Nb} / \mathrm{Al}$ seems slightly elevated through the siliceous claystone of Unit III. $\mathrm{Cr} / \mathrm{Al}$ may be slightly higher through the diatomaceous interval of Unit II and also through portions of the siliceous claystones of Unit III, implying that a portion of the $\mathrm{Cr}$ is carried by the siliceous component. $\mathrm{Sr} / \mathrm{Al}$ and $\mathrm{Ba} / \mathrm{Al}$ clearly are enriched through the diatomaceous intervals, confirming their biogenic associations.

\section{Site 795}

\section{Major Elements}

The diatom-rich sequences at Site 795 (Units II and III), although relatively high in $\mathrm{SiO}_{2}$, do not show the well-developed $\mathrm{SiO}_{2}$ maximum that is present at Site 794 (Fig. 3A). Instead, $\mathrm{SiO}_{2}$ concentrations gradually increase from near-surface values of $\sim 64 \mathrm{wt} \%$ to a maxi- mum of $\sim 77 \mathrm{wt} \%$ at the opal-A/opal-CT transition ( $\sim 325 \mathrm{mbsf})$. These maximum concentrations are slightly lower than the maximum $\mathrm{SiO}_{2}$ observed at Site 794 ( $81 \mathrm{wt} \%)$. The $\mathrm{SiO}_{2}$ scatter through Unit IV is affected by sampling resolution and reflects the increasing abundance of diagenetic porcellanite and chert sequences, which commonly contain zones of elevated $\mathrm{SiO}_{2}$ concentrations. The remaining major elements show absolute concentrations that generally follow $\mathrm{Al}$ and are diluted by the $\mathrm{SiO}_{2}$ component (Fig. $3 \mathrm{~A}$ and Table 4).

$\mathrm{Si} / \mathrm{Al}$ also shows a only slight increase through the ooze (Fig. 3B), consistent with the minimal $\mathrm{SiO}_{2}$ increase described previously. Below the opal-A/opal-CT transition, $\mathrm{Ti} / \mathrm{Al}, \mathrm{Na} / \mathrm{Al}, \mathrm{Fe} / \mathrm{Al}$, and $\mathrm{Mg} / \mathrm{Al}$ all decrease to minimum values at depth (Fig. 3B), implying some diagenetic behavior, although the specific relationships are unclear. The $\mathrm{Na} / \mathrm{Al}$ profile does not show the pronounced maximum through the siliceous interval that was recorded at Site 794 (Unit II at both sites). Al-normalized $\mathrm{Ca}, \mathrm{P}$, and, most noticeably, Fe profiles each show an increase from the diatom ooze of Unit II to a relative maximum through the diatom claystones of Unit III (Fig. 3B).

\section{Rare Earth Elements}

¿REE concentrations at Site 795 decrease from $~ 190$ to $~ 160 \mathrm{ppm}$ through Unit I, decrease further to $\sim 115 \mathrm{ppm}$ in the diatom ooze of Unit II, and decrease only slightly to the base of Unit III, where $\Sigma$ REE is $\sim 100$ ppm (Fig. 4). $\mathrm{R}$ RE appears higher in the siliceous claystones of Unit IV, although only a few samples were analyzed. The high $\Sigma \mathrm{REE}$ and $\Sigma \mathrm{REE} / \mathrm{Al}$ at $43.7 \mathrm{mbsf}$ are coincident with an anomalously low Eu/Eu* as well as high $\mathrm{Na}_{2} \mathrm{O}$ and $\mathrm{Zr}$ concentrations. Interelement correlations (Table 6) show that the REEs are only slightly diluted by the siliceous biogenic component and are closely affiliated with the aluminosilicate component $\left(\mathrm{Al}_{2} \mathrm{O}_{3}, r=0.92 ; \mathrm{K}_{2} \mathrm{O}, r=0.94\right)$. The other high $r$ values (e.g., $\mathrm{P}_{2} \mathrm{O}_{5}$ ) also reflect the aluminosilicate input, as the Al-normalized major element ratios are similar to that of average shale, as at Site 794.

The $\mathrm{Ce} / \mathrm{Ce} *$ profile increases from values ranging between 0.98 and 1.11 in Unit I to higher values ( 1.30) at depth in Unit IV (Fig. 4). There is no change in $\mathrm{Ce} / \mathrm{Ce}^{*}$ across either the opal-A/opal-CT or opal$\mathrm{CT} /$ quartz diagenetic transition. Correlation coefficients, however, suggest a weak and negative association with virtually all components except $\mathrm{SiO}_{2}$, most likely reflecting a $\mathrm{SiO}_{2}$ dilution effect (Table 6). Note, however, that unlike at Site $794 \mathrm{Ce} / \mathrm{Ce}$ * does not correlate with $\mathrm{MnO}$. Most $\mathrm{Eu} / \mathrm{Eu}^{*}$ values range between 0.90 and 1.08 and are essentially uniform (within error; Fig. 4). The anomalously low Eu/Eu* in Unit I corresponds with high $\Sigma R E E$, as described previously. Unlike at Site 794, there is no Eu/Eu* maximum within the diatom ooze of Unit II (nor is there a concomitant $\mathrm{Na}$ or $\mathrm{Na} / \mathrm{Al}$ increase).

The $\mathrm{La}_{\mathrm{n}} / \mathrm{Yb}_{\mathrm{n}}$ profile (Fig. 4) can be divided into three sections: (1) increasing from $\sim 1$ to $\sim 1.25$ through Unit I claystones, (2) decreasing to a broad relative minimum of $\sim 0.84$ through the diatom ooze of Unit II and diatomaceous claystone of Unit III, and (3) increasing again to 1.26 through Unit IV siliceous claystones. Despite the continuity of the profile, $\mathrm{La}_{\mathrm{n}} / \mathrm{Yb}_{\mathrm{n}}$ correlates only moderately (and negatively) with $\mathrm{SiO}_{2}$ and $\mathrm{Eu} / \mathrm{Eu}^{*}$ (Table 6). The low $\mathrm{La}_{\mathrm{n}} / \mathrm{Yb}_{\mathrm{n}}(=0.49)$ at the base of Unit $\mathrm{I}$ is coincident with high $\mathrm{Eu} / \mathrm{Eu} *$ and low $\mathrm{Ce} / \mathrm{Ce} *$, as well as high $\mathrm{Mn} / \mathrm{Al}$ and $\mathrm{Ca} / \mathrm{Al}$, and as such probably reflects $\mathrm{REE}$ fractionation within a manganese carbonate.

\section{Trace Elements}

Some trace element profiles at Site 795 (Fig. 5A) are generally smooth through the entire sequence (e.g., $\mathrm{Sr}, \mathrm{Zr}$ ), although others show scatter around a constant trend (e.g., $\mathrm{Nb}$ ). Chromium concentrations double within Unit III to values between 120 and $160 \mathrm{ppm}$. This is the same interval through which $\mathrm{Ca} / \mathrm{Al}, \mathrm{P} / \mathrm{Al}$, and $\mathrm{Fe} / \mathrm{Al}$ profiles increased as well (see the preceding). $\mathrm{Sr} / \mathrm{Al}$ and $\mathrm{Ba} / \mathrm{Al}$, which at Site 794 showed a clear siliceous influence, record only an extremely slight increase through Unit II (Fig. 5B). Correlation coeffi- 
Table 2. Rare earth element and trace element data (ppm) from Leg 127 squeeze-cake residues and physical-property samples.

\begin{tabular}{|c|c|c|c|c|c|c|c|c|c|c|c|c|c|c|c|c|c|c|c|c|c|c|c|c|c|}
\hline $\begin{array}{l}\text { Core, section, } \\
\text { interval }(\mathrm{cm})\end{array}$ & La & $\mathrm{Ce}$ & $\operatorname{Pr}$ & Nd & Sm & Eu & Gd & $\mathrm{Tb}$ & Dy & Ho & Er & $\mathrm{Tm}$ & $\mathrm{Yb}$ & Lu & EREE & $\mathrm{Ce} / \mathrm{Ce}^{*}$ & $\mathrm{Eu} / \mathrm{Eu} *$ & $\mathrm{La}_{n} / \mathrm{Yb}_{\mathrm{n}}$ & $\mathrm{Cr}$ & $\mathrm{Rb}$ & $\mathrm{Sr}$ & $\mathrm{Y}$ & $\mathrm{Zr}$ & $\mathrm{Nb}$ & $\mathrm{Ba}$ \\
\hline Shale & 41 & 83 & 10.1 & 38 & 7.5 & 1.61 & 6.35 & 1.23 & 5.49 & 1.34 & 3.75 & 0.63 & 3.51 & 0.61 & 204 & 1.00 & 1.00 & 1.00 & & & & & & & \\
\hline \multicolumn{26}{|l|}{ 127-794A. } \\
\hline $1 \mathrm{H}-3,140-145$ & 33.7 & 81.6 & 9.48 & 32.2 & 6.37 & 1.32 & 5.19 & 0.88 & 4.86 & 0.84 & 2.29 & 0.34 & 2.43 & 0.34 & 182 & 1.12 & 0.98 & 1.19 & 95 & 132 & 160 & 19 & 152 & 29 & 975 \\
\hline $3 \mathrm{H}-5,140-145$ & 33.3 & 77.4 & 9.58 & 29.4 & 5.65 & 1.27 & 5.16 & 0.75 & 4.12 & 0.67 & 2.36 & 0.30 & 2.17 & 0.30 & 172 & 1.06 & 1.01 & 1.31 & 97 & 132 & 188 & 24 & 146 & 17 & 826 \\
\hline $6 \mathrm{H}-4,145-150$ & 38.9 & 86.8 & 10.3 & 36.1 & 7.01 & 1.62 & 6.15 & 0.81 & 5.25 & 0.76 & 2.43 & 0.48 & 2.48 & 0.29 & 199 & 1.07 & 1.06 & 1.34 & 165 & 139 & 121 & 27 & 140 & 21 & 1210 \\
\hline $9 \mathrm{H}-4,145-150$ & 34.8 & 81.9 & 9.00 & 31.3 & 6.29 & 1.39 & 5.34 & 0.80 & 4.76 & 0.91 & 2.52 & 0.29 & 2.23 & 0.29 & 182 & 1.14 & 1.03 & 1.34 & 92 & 132 & 184 & 24 & 162 & 16 & 2750 \\
\hline $12 \mathrm{H}-4,145-150$ & 25.3 & 66.0 & 6.93 & 23.5 & 4.52 & 1.04 & 4.43 & 0.61 & 3.60 & 0.52 & 1.77 & 0.24 & 1.65 & 0.24 & 140 & 1.22 & 0.99 & 1.31 & 81 & 117 & 144 & & 105 & 19 & 1670 \\
\hline $15 \mathrm{H}-4,145-150$ & 22.4 & 56.6 & 5.99 & 20.6 & 3.95 & 1.05 & 3.49 & 0.54 & 3.29 & 0.54 & 1.53 & 0.28 & 1.61 & 0.23 & 122 & 1.20 & 1.21 & 1.19 & 72 & 96 & 144 & 14 & 99 & 12 & 2600 \\
\hline $22 \mathrm{X}-4,145-150$ & 13.6 & 45.2 & 4.07 & 14.1 & 2.90 & 0.82 & 2.61 & 0.42 & 2.26 & 0.33 & 1.15 & 0.16 & 1.20 & 0.14 & 89 & 1.48 & 1.28 & 0.97 & 61 & 66 & 163 & 13 & 69 & 13 & 3580 \\
\hline $25 \mathrm{X}-4,145-150$ & 20.6 & 63.4 & 6.08 & 20.9 & 4.04 & 0.95 & 3.55 & 0.53 & 3.19 & 0.59 & 1.71 & 0.23 & 1.81 & 0.23 & 128 & 1.38 & 1.08 & 0.97 & 102 & 86 & 146 & 25 & 79 & & 2000 \\
\hline $29 \mathrm{X}-4,145-150$ & 29.6 & 93.6 & 8.33 & 28.5 & 5.71 & 1.27 & 5.16 & 0.83 & 4.58 & 0.69 & 2.17 & 0.34 & 2.34 & 0.31 & 183 & 1.46 & 1.00 & 1.08 & 92 & 116 & 147 & 31 & 109 & 17 & 1920 \\
\hline $33 \times-2,140-145$ & 30.4 & 90.1 & 8.62 & 29.3 & 5.90 & 1.27 & 4.87 & 0.78 & 4.20 & 0.64 & 2.12 & 0.25 & 1.94 & 0.28 & 181 & 1.36 & 1.02 & 1.34 & 89 & 135 & 116 & 19 & 126 & & 1450 \\
\hline $36 \mathrm{X}-4,145-150$ & 28.6 & 102.6 & 8.50 & 29.1 & 6.37 & 1.56 & 6.37 & 0.88 & 5.07 & 0.92 & 2.90 & 0.38 & 2.52 & 0.42 & 196 & 1.61 & 1.05 & 0.97 & 78 & 122 & 212 & 27 & 116 & 30 & 3810 \\
\hline
\end{tabular}

127-794B-

$\begin{array}{lllllllllllllllll}12 \mathrm{R}-1,145-150 & 16.1 & 40.6 & 4.58 & 15.4 & 3.21 & 0.70 & 2.84 & 0.43 & 2.47 & 0.46 & 1.50 & 0.21 & 2.01 & 0.21 & 91 & 1.15\end{array}$

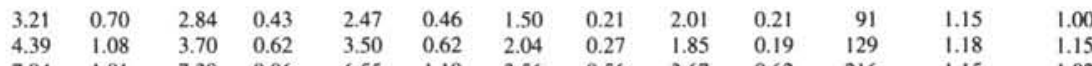

127-795A-

\begin{tabular}{|c|c|c|c|c|c|c|c|c|c|c|c|c|c|c|c|c|c|c|c|c|c|c|c|c|c|}
\hline $1 \mathrm{H}-4,145-150$ & 34.9 & 82.7 & 9.45 & 31.6 & 6.54 & 1.46 & 6.42 & 0.88 & 5.34 & 0.93 & 2.89 & 0.37 & 2.79 & 0.37 & 187 & 1.11 & 0.97 & 1.07 & 89 & 128 & 173 & 15 & 147 & 29 & 810 \\
\hline $2 \mathrm{H}-4,145-150$ & 40.0 & 84.4 & 11.2 & 38.2 & 8.62 & 2.05 & 7.11 & 1.08 & 6.89 & 1.08 & 3.55 & 0.54 & 3.66 & 0.65 & 209 & 0.98 & 1.12 & 0.94 & 95 & 139 & 155 & 38 & 168 & 21 & 740 \\
\hline $3 \mathrm{H}-4,145-150$ & 35.5 & 81.4 & 9.35 & 32.8 & 6.73 & 1.45 & 6.24 & 0.91 & 5.26 & 1.04 & 2.86 & 0.38 & 2.44 & 0.41 & 187 & 1.09 & 0.96 & 1.25 & 82 & 100 & 148 & 27 & 125 & 25 & 1210 \\
\hline $4 \mathrm{H}-4,145-150$ & 32.2 & 74.7 & 8.39 & 29.3 & 6.13 & 1.37 & 5.97 & 0.80 & 4.83 & 0.92 & 2.79 & 0.34 & 2.55 & 0.38 & 171 & 1.11 & 0.97 & 1.08 & 97 & 121 & 176 & & 161 & 31 & 1310 \\
\hline $5 \mathrm{H}-4,145-150$ & 43.7 & 95.6 & 11.3 & 37.0 & 7.48 & 1.27 & 7.58 & 1.07 & 5.99 & 1.23 & 3.38 & 0.47 & 3.26 & 0.49 & 220 & 1.05 & 0.72 & 1.15 & 73 & 103 & 173 & 38 & 243 & 26 & 683 \\
\hline $6 \mathrm{H}-4,145-150$ & 31.7 & 74.7 & 8.58 & 30.2 & 6.45 & 1.45 & 6.57 & 0.88 & 5.18 & 1.04 & 2.68 & 0.37 & 2.52 & 0.36 & 173 & 1.11 & 0.95 & 1.08 & 88 & 96 & 171 & 20 & 120 & 19 & 1450 \\
\hline $7 \mathrm{H}-4,145-150$ & 33.1 & 74.8 & 8.67 & 29.7 & 6.42 & 1.40 & 6.42 & 0.81 & 4.79 & 0.97 & 2.52 & 0.32 & 2.33 & 0.36 & 173 & 1.08 & 0.93 & 1.22 & 98 & 119 & 179 & & 114 & 12 & 881 \\
\hline $8 \mathrm{H}-4,145-150$ & 30.0 & 66.3 & 7.81 & 27.2 & 5.64 & 1.26 & 5.62 & 0.78 & 4.58 & 0.91 & 2.64 & 0.38 & 2.39 & 0.38 & 156 & 1.06 & 0.96 & 1.07 & 87 & 102 & 153 & 11 & 112 & 16 & 745 \\
\hline $9 \mathrm{H}-4,145-150$ & 32.5 & 73.2 & 8.55 & 29.4 & 6.26 & 1.33 & 5.84 & 0.75 & 4.48 & 0.84 & 2.38 & 0.35 & 2.24 & 0.31 & 168 & 1.08 & 0.94 & 1.24 & 88 & 121 & 140 & 28 & 145 & 26 & 1170 \\
\hline $10 \mathrm{H}-1,145-150$ & 33.6 & 72.8 & 8.86 & 29.6 & 6.01 & 1.31 & 5.77 & 0.78 & 4.68 & 0.84 & 2.54 & 0.36 & 2.28 & 0.33 & 170 & 1.03 & 0.95 & 1.26 & 103 & 138 & 185 & 17 & 158 & 27 & 1170 \\
\hline $12 \mathrm{H}-4,140-145$ & 26.0 & 56.4 & 8.29 & 28.2 & 8.41 & 2.06 & 7.28 & I.18 & 6.74 & 1.32 & 4.44 & 0.93 & 4.54 & 0.76 & 157 & 0.93 & $\mathrm{t} .13$ & 0.49 & 92 & 89 & 145 & 19 & 114 & 21 & 938 \\
\hline $15 \mathrm{H}-4,140-145$ & 21.3 & 49.3 & 5.92 & 20.2 & 3.20 & 0.69 & 3.44 & 0.38 & 2.98 & 0.50 & 1.68 & 0.19 & 1.14 & 0.16 & 111 & 1.08 & 0.89 & 1.60 & 89 & 90 & 121 & & 118 & & 906 \\
\hline $18 \mathrm{H}-4,140-145$ & 21.6 & 57.1 & 6.32 & 21.0 & 3.36 & 0.67 & 3.10 & 0.47 & 3.28 & 0.59 & 1.77 & 0.18 & 1.43 & 0.18 & 121 & 1.19 & 0.89 & 1.29 & 90 & 75 & 123 & 11 & 95 & 24 & 1070 \\
\hline $21 X-4,140-145$ & 18.4 & 43.9 & 4.79 & 17.5 & 3.88 & 0.94 & 3.61 & 0.49 & 3.33 & 0.61 & 1.75 & 0.25 & 1.57 & 0.24 & 101 & 1.15 & 1.08 & 1.00 & 81 & 99 & 116 & 17 & 75 & & 924 \\
\hline $25 \mathrm{X}-3,140-145$ & 23.5 & 58.2 & 6.39 & 22.0 & 5.05 & 1.11 & 4.79 & 0.64 & 3.80 & 0.75 & 2.19 & 0.33 & 2.15 & 0.33 & 131 & 1.16 & 0.97 & 0.94 & 95 & 105 & 131 & 24 & 118 & 12 & 992 \\
\hline $29 \mathrm{X}-2,140-145$ & 19.0 & 47.2 & 5.24 & 18.0 & 3.72 & 0.91 & 3.66 & 0.54 & 3.17 & 0.58 & 1.84 & 0.26 & 1.84 & 0.28 & 106 & 1.1 & 1.06 & 0.88 & 92 & 97 & 138 & 17 & 91 & 13 & 891 \\
\hline $30 \mathrm{X}-2,145-150$ & 17.9 & 47.9 & 5.27 & 17.1 & 3.52 & 0.87 & 3.65 & 0.48 & 2.90 & 0.59 & 1.64 & 0.25 & 1.68 & 0.26 & 104 & 1.20 & 1.04 & 0.91 & 148 & 99 & 127 & 18 & 86 & 25 & 905 \\
\hline $31 X-4,145-150$ & 16.7 & 45.0 & 4.95 & 16.7 & 3.46 & 0.86 & 3.64 & 0.48 & 2.94 & 0.62 & 1.72 & 0.24 & 1.70 & 0.27 & 99 & 1.21 & 1.04 & 0.84 & 160 & 94 & 109 & & 86 & 18 & 824 \\
\hline $34 \mathrm{X}-1,100-102$ & n.a. & n.a. & n.a. & n.a. & n.a. & n.a. & n.a. & n.a. & n.a. & n.a. & n.a. & n.a. & n.a. & n.a. & n.a. & n.a. & n.a. & n.a. & 142 & 107 & 121 & & 75 & & 951 \\
\hline $34 X-3,100-102$ & n.a. & n.a. & n.a. & n.a. & n.a. & n.a. & n.a. & n.a. & n.a. & n.a. & n.a. & n.a. & n.a. & n.a. & n.a. & n.a. & n.a. & n.a. & 153 & 98 & 141 & 20 & 91 & & 1010 \\
\hline $34 X-4,100-102$ & n.a. & n.a. & n.a. & n.a. & n.a. & n.a. & n.a. & n.a. & n.a. & n.a. & n.a. & n.a. & n.a. & n.a. & n.a. & n.a. & n.a. & n.a. & n.a. & n.a. & n.a. & n.a. & n.a. & n.a. & n.a. \\
\hline $34 X-5,140-145$ & 19.0 & 46.8 & 5.42 & 17.7 & 3.86 & 0.87 & 3.88 & 0.54 & 3.42 & 0.78 & 1.96 & 0.33 & 1.94 & 0.30 & 107 & 1.13 & 0.96 & 0.84 & 98 & 96 & 136 & 29 & 112 & & 847 \\
\hline $34 \mathrm{X}-6,100-102$ & n.a. & n.a. & n.a. & n.a. & n.a. & n.a. & n.a. & n.a. & n.a. & n.a. & n.a. & n.a. & n.a. & n.a. & n.a. & n.a. & n.a. & n.a. & n.a. & n.a. & n.a. & n.a. & n.a. & n.a. & n.a. \\
\hline $34 X-7,39-40$ & n.a. & n.a. & n.a. & n.a. & n.a. & n.a. & n.a. & n.a. & n.a. & n.a. & n.a. & n.a. & n.a. & п.a. & n.a. & n.a. & n.a. & n.a. & 124 & 86 & 160 & 18 & 91 & & 1060 \\
\hline $35 \mathrm{X}-1,100-102$ & n.a. & n.a. & n.a. & n.a. & n.a. & n.a. & n.a. & n.a. & n.a. & n.a. & n.a. & n.a. & n.a. & n.a. & n.a. & n.a. & n.a. & n.a. & 139 & 97 & 115 & 16 & 78 & & 897 \\
\hline $35 \mathrm{X}-2,145-150$ & 17.2 & 47.4 & 5.07 & 17.2 & 3.54 & 0.85 & 3.68 & 0.50 & 3.03 & 0.63 & 1.83 & 0.26 & 1.83 & 0.28 & 103 & 1.24 & 1.01 & 0.80 & 90 & 69 & 109 & 19 & 99 & 18 & 809 \\
\hline $35 \mathrm{X}-3,100-102$ & n.a. & n.a. & n.a. & n.a. & n.a. & n.a. & n.a. & n.a. & n.a. & n.a. & n.a. & n.a. & n.a. & n.a. & n.a. & n.a. & n.a. & n.a. & 135 & 91 & 118 & 13 & 62 & 15 & 871 \\
\hline $35 \times-4,100-102$ & n.a. & n.a. & n.a. & n.a. & n.a. & n.a. & n.a. & n.a. & n.a. & n.a. & n.a. & n.a. & n.a. & n.a. & n.a. & n.a. & n.a. & n.a. & 156 & 110 & 135 & & 104 & 18 & 963 \\
\hline $35 \mathrm{X}-6,100-102$ & n.a. & n.a. & n.a. & n.a. & n.a. & n.a. & n.a. & n.a. & n.a. & n.a. & n.a. & n.a. & n.a. & n.a. & n.a. & n.a. & n.a. & n.a. & 161 & 106 & 136 & 37 & 112 & 27 & 1090 \\
\hline $37 \mathrm{X}-1,99-100$ & n.a. & n.a. & n.a. & n.a. & n.a. & n.a. & n.a. & n.a. & n.a. & n.a. & n.a. & n.a. & n.a. & n.a. & n.a. & n.a. & n. & n.a. & 127 & 81 & 108 & & 77 & 24 & 784 \\
\hline $37 \mathrm{X}-1,145-150$ & 15.9 & 43.4 & 4.68 & 15.8 & 3.20 & 0.78 & 3.25 & 0.42 & 2.60 & 0.54 & 1.54 & 0.23 & 1.56 & 0.24 & 94 & 1.23 & 1.03 & 0.87 & 89 & 75 & 112 & & 137 & 17 & 823 \\
\hline
\end{tabular}


Table 2 (continued).

\begin{tabular}{|c|c|c|c|c|c|c|c|c|c|c|c|c|c|c|c|c|c|c|c|c|c|c|c|c|c|}
\hline $\begin{array}{l}\text { Core, section, } \\
\text { interval }(\mathrm{cm})\end{array}$ & $\mathrm{La}$ & $\mathrm{Ce}$ & Pr & $\mathrm{Nd}$ & Sm & $\mathrm{Eu}$ & Gd & $\mathrm{Tb}$ & Dy & Ho & $\mathrm{Er}$ & $\mathrm{Tm}$ & $\mathrm{Yb}$ & Lu & EREE & $\mathrm{Ce} / \mathrm{Ce}^{*}$ & $\mathrm{Eu} / \mathrm{Eu}^{*}$ & $\mathrm{La}_{n} / \mathrm{Yb}_{n}$ & $\mathrm{Cr}$ & $\mathrm{Rb}$ & $\mathrm{Sr}$ & $\mathrm{Y}$ & $\mathrm{Zr}$ & $\mathrm{Nb}$ & $\mathrm{Ba}$ \\
\hline \multicolumn{26}{|l|}{ 127-795B- } \\
\hline IR-1, 140-145 & 22.1 & 58.7 & 6.44 & 21.4 & 4.40 & 1.05 & 4.56 & 0.60 & 3.74 & 0.76 & 2.26 & 0.33 & 2.24 & 0.34 & 129 & 1.20 & 1.00 & 0.84 & 95 & 108 & 126 & 27 & 130 & 30 & 945 \\
\hline${ }^{6} 9 \mathrm{R}-2,111-113$ & n.a. & n.a. & n.a. & n.a. & n.a. & n.a. & n.a. & n.a. & n.a. & n.a. & n.a. & n.a. & n.a. & n.a. & n.a. & n.a. & n.a. & n.a. & 100 & 55 & 55 & 11 & 49 & & 717 \\
\hline b $11 \mathrm{R}-3,81-83$ & n.a. & n.a. & n.a. & n.a. & n.a. & n.a. & n.a. & n.a. & n.a. & n.a. & n.a. & n.a. & n.a. & n.a. & n.a. & n.a. & n.a. & n.a. & 91 & & 125 & & 111 & 12 & 819 \\
\hline${ }^{b} 12 R-3,96-98$ & n.a. & n.a. & n.a. & n.a. & n.a. & n.a. & n.a. & n.a. & n.a. & n.a. & n.a. & n.a. & n.a. & n.a. & n.a. & n.a. & n.a. & n.a. & 89 & 113 & 126 & 19 & 114 & & 808 \\
\hline $13 R-2,140-145$ & 24.9 & 74.5 & 7.42 & 24.8 & 4.97 & 1.16 & 4.79 & 0.63 & 3.67 & 0.74 & 2.11 & 0.30 & 2.05 & 0.30 & 152 & 1.34 & 1.02 & 1.04 & 86 & 115 & 135 & 29 & 123 & 16 & 800 \\
\hline b $13 R-3,63-65$ & n.a. & n.a. & n.a. & n.a. & n.a. & n.a. & n.a. & n.a. & n.a. & n.a. & n.a. & n.a. & n.a. & n.a. & n.a. & n.a. & n.a. & n.a. & 85 & 127 & 128 & 30 & 118 & 23 & 801 \\
\hline${ }^{b} 14 R-3,127-129$ & n.a. & n.a. & n.a. & n.a. & n.a. & n.a. & n.a. & n.a. & n.a. & n.a. & n.a. & n.a. & n.a. & n.a. & n.a. & n.a. & n.a. & n.a. & 58 & 68 & 231 & 18 & 128 & 18 & 1290 \\
\hline $19 \mathrm{R}-1,140-145$ & 17.8 & 48.7 & 4.87 & 16.2 & 2.51 & 0.46 & 2.51 & 0.29 & 2.17 & 0.43 & 1.23 & 0.16 & 1.21 & 0.17 & 99 & 1.28 & 0.79 & 1.26 & 77 & 106 & 94 & & 114 & 13 & 687 \\
\hline \multicolumn{26}{|l|}{ 127-796A- } \\
\hline $2 \mathrm{H}-4,145-150$ & 24.6 & 56.6 & 6.73 & 23.3 & 5.28 & 1.41 & 5.11 & 0.73 & 4.31 & 0.79 & 2.39 & 0.35 & 2.37 & 0.38 & 134 & 1.08 & 1.16 & 0.89 & 82 & 109 & 231 & 25 & 126 & 18 & 3030 \\
\hline $5 \mathrm{H}-5,145-150$ & 42.6 & 96.0 & 12.4 & 49.2 & 14.7 & 3.73 & 14.3 & 2.36 & 13.0 & 2.50 & 8.90 & 1.79 & 9.04 & 1.86 & 272 & 1.02 & 1.10 & 0.40 & 85 & 100 & 247 & 32 & 120 & & 2530 \\
\hline $9 \mathrm{X}-2,145-150$ & 25.8 & 55.5 & 7.74 & 27.7 & 8.13 & 1.86 & 7.74 & 1.17 & 6.27 & 1.37 & 4.11 & 0.78 & 4.21 & 0.88 & 153 & 0.96 & 1.00 & 0.52 & 88 & 111 & 129 & 32 & 128 & 17 & 1410 \\
\hline $11 X-1,145-150$ & 23.9 & 56.6 & 6.81 & 23.1 & 4.02 & 1.03 & 3.35 & 0.53 & 3.47 & 0.70 & 1.90 & 0.34 & 1.59 & 0.26 & 128 & 1.08 & 1.21 & 1.29 & 97 & 116 & 154 & 17 & 119 & 15 & 640 \\
\hline \multicolumn{26}{|l|}{ 127-797B- } \\
\hline $1 \mathrm{H}-2,145-150$ & 37.8 & 85.2 & 9.84 & 32.0 & 6.03 & 1.23 & 5.74 & 0.75 & 4.40 & 0.77 & 2.37 & 0.33 & 2.17 & 0.33 & 189 & 1.08 & 0.90 & 1.49 & 114 & 157 & 155 & 32 & 188 & 15 & 769 \\
\hline $2 \mathrm{H}-4,145-150$ & 31.8 & 70.1 & 8.48 & 27.2 & 5.11 & 1.01 & 4.34 & 0.61 & 3.59 & 0.68 & 1.95 & 0.31 & 2.26 & 0.28 & 158 & 1.05 & 0.92 & 1.20 & 100 & 140 & 156 & 13 & 166 & 19 & 835 \\
\hline $3 \mathrm{H}-5,140-145$ & 44.2 & 101 & 11.7 & 39.0 & 7.78 & 1.59 & 7.27 & 1.03 & 5.65 & 1.10 & 3.02 & 0.42 & 2.71 & 0.42 & 227 & 1.09 & 0.91 & 1.40 & 108 & 146 & 161 & 41 & 195 & 15 & 778 \\
\hline $4 \mathrm{H}-4,145-150$ & 33.7 & 70.2 & 8.77 & 29.4 & 6.31 & 1.27 & 5.56 & 0.75 & 4.36 & 0.80 & 2.37 & 0.32 & 2.14 & 0.30 & 166 & 1.00 & 0.92 & 1.35 & 83 & 120 & 347 & 36 & 133 & 14 & 576 \\
\hline $5 \mathrm{H}-4,145-150$ & 46.0 & 106 & 11.5 & 39.3 & 8.09 & 1.59 & 7.96 & 1.03 & 5.82 & 1.11 & 3.00 & 0.44 & 2.76 & 0.41 & 235 & 1.13 & 0.84 & 1.43 & 96 & 130 & 139 & 35 & 186 & 28 & 802 \\
\hline $6 \mathrm{H}-4,140-145$ & 35.7 & 82.5 & 10.2 & 31.5 & 6.38 & 1.19 & 5.21 & 1.01 & 4.62 & 0.89 & 2.76 & 0.40 & 2.26 & 0.26 & 185 & 1.06 & 0.89 & 1.35 & 93 & 132 & 180 & 27 & 172 & 21 & 1720 \\
\hline $7 \mathrm{H}-4,145-150$ & 36.5 & 82.0 & 9.53 & 31.8 & 6.68 & 1.52 & 6.35 & 0.96 & 5.08 & 1.02 & 2.93 & 0.39 & 2.52 & 0.35 & 188 & 1.08 & 1.00 & 1.24 & 104 & 148 & 154 & 32 & 121 & 14 & 1450 \\
\hline $8 \mathrm{H}-4,145-150$ & 35.2 & 81.4 & 9.07 & 31.5 & 6.85 & 1.57 & 6.38 & 0.86 & 5.10 & 0.99 & 2.85 & 0.40 & 2.56 & 0.42 & 185 & 1.12 & 1.02 & 1.18 & 90 & 118 & 135 & 29 & 130 & 25 & 885 \\
\hline $9 \mathrm{H}-4,140-145$ & 96.2 & 178 & 19.5 & 55.6 & 8.98 & 1.45 & 7.20 & 1.17 & 6.67 & 1.25 & 3.86 & 0.61 & 3.25 & 0.53 & 385 & 1.01 & 0.77 & 2.53 & 69 & 171 & 180 & 65 & 465 & 107 & 1080 \\
\hline $10 \mathrm{H}-4,145-150$ & 32.1 & 87.0 & 8.91 & 30.4 & 6.69 & 1.56 & 6.07 & 0.82 & 4.63 & 0.90 & 2.93 & 0.38 & 2.43 & 0.3 & 185 & 1.26 & 1.05 & 1.13 & 102 & 128 & 207 & 16 & 136 & & 2780 \\
\hline $12 \mathrm{H}-4,145-150$ & 81.0 & 160 & 16.2 & 47.8 & 3.40 & 1.31 & 8.18 & 1.04 & 5.77 & 1.13 & 3.37 & 0.50 & 3.40 & 0.47 & 334 & 1.08 & 0.93 & 2.04 & 63 & 139 & 138 & 50 & 349 & 97 & 1710 \\
\hline $15 \mathrm{H}-4,145-150$ & 36.6 & 92.7 & 9.96 & 34.4 & 7.14 & 1.68 & 6.77 & 0.89 & 5.32 & 1.01 & 2.75 & 0.37 & 2.61 & 0.41 & 203 & 1.19 & 1.04 & 1.20 & 105 & 145 & 179 & & 132 & 12 & 3190 \\
\hline $18 \mathrm{H}-4,145-150$ & 20.3 & 51.3 & 5.09 & 18.1 & 3.93 & 0.97 & 4.26 & 0.56 & 3.91 & 0.87 & 2.75 & 0.43 & 3.07 & 0.60 & 116 & 1.24 & 1.0 & 0.57 & 58 & 71 & 181 & 10 & 47 & 11 & 2540 \\
\hline $21 \times-4,140-145$ & 28.9 & 83.2 & 8.41 & 29.0 & 5.52 & 1.33 & 5.09 & 0.73 & 3.98 & 0.75 & 2.08 & 0.30 & 1.95 & 0.32 & 172 & 1.3 & 1.0 & 1.27 & 87 & 110 & 154 & & 133 & 18 & 3060 \\
\hline $24 \mathrm{X}-5,140-145$ & 23.8 & 79.9 & 7.18 & 24.8 & 5.10 & 1.36 & 7.37 & 0.71 & 4.17 & 0.84 & 2.34 & 0.35 & 2.25 & 0.33 & 160 & 1.49 & 0.9 & 0.91 & 114 & 107 & 184 & 29 & 100 & 23 & 3960 \\
\hline $27 \mathrm{X}-6,140-145$ & 31.7 & 90.9 & 8.91 & 30.5 & 6.91 & 1.62 & 6.23 & 0.90 & 5.12 & 0.98 & 2.82 & 0.41 & 2.43 & 0.38 & 190 & 1.32 & 1.06 & 1.12 & 89 & 102 & 182 & 21 & 133 & 22 & 3160 \\
\hline $28 \mathrm{X}-1,145-150$ & 29.4 & 101 & 9.00 & 30.4 & 6.24 & 1.56 & 7.17 & 0.85 & 4.84 & 0.97 & 2.73 & 0.40 & 2.81 & 0.40 & 198 & 1.52 & 0.98 & 0.90 & 171 & 136 & 133 & 30 & 111 & & 2380 \\
\hline${ }^{3} 0 \mathrm{X}-1,99-101$ & n.a. & n.a. & n.a. & n.a. & n.a. & n.a. & n.a. & n.a. & n.a. & n.a. & n.a. & n.a. & n.a. & n.a. & n.a. & n.a. & n.a. & n.a. & 167 & 137 & 175 & 13 & 105 & 22 & 3910 \\
\hline $30 \mathrm{X}-1,145-150$ & 27.8 & 92.3 & 8.50 & 29.2 & 6.09 & 1.67 & 7.64 & 0.83 & 5.00 & 1.00 & 2.90 & 0.42 & 2.83 & 0.43 & 187 & 1.46 & 1.03 & 0.84 & 105 & 105 & 233 & 30 & 119 & 14 & 3900 \\
\hline $31 X-2,98-100$ & n.a. & n.a. & n.a. & n.a. & n.a. & n.a. & n.a. & n.a. & n.a. & n.a. & n.a. & n.a. & n.a. & n.a. & n.a. & n.a. & n.a. & n.a. & 144 & 116 & 210 & 22 & 103 & & 3320 \\
\hline $31 X-5,96-98$ & n.a. & n.a. & n.a. & n.a. & n.a. & n.a. & n.a. & n.a. & n.a. & n.a. & n.a. & n.a. & n.a. & n.a. & n.a. & n.a. & n.a. & n.a. & 167 & 128 & 160 & 26 & 116 & 39 & 2510 \\
\hline$b_{32 X-2,98-100}$ & n.a. & n.a. & n.a. & n.a. & n.a. & n.a. & n.a. & n.a. & n.a. & n.a. & n.a. & n.a. & n.a. & n.a. & n.a. & n.a. & n.a. & n.a. & 171 & 104 & 211 & 38 & 110 & & 3350 \\
\hline $32 \mathrm{X}-3,145-150$ & 32.1 & 103.8 & 9.79 & 33.5 & 6.98 & 1.80 & 8.46 & 0.94 & 5.48 & 1.07 & 2.98 & 0.42 & 2.94 & 0.43 & 211 & 1.43 & 0.99 & 0.93 & 94 & 112 & 191 & 29 & 128 & 11 & 3020 \\
\hline $32 X-5,99-100$ & n.a. & n.a. & n.a. & n.a. & n.a. & n.a. & n.a. & & n.a. & n.a. & n.a. & n.a. & n.a. & n.a. & n.a. & n.a. & n.a. & & 156 & 130 & 198 & 43 & 107 & 23 & 3350 \\
\hline $33 \mathrm{X}-1,100-101$ & n.a. & n.a. & n.a. & n.a. & n.a. & n.a. & n.a. & n.a. & $\begin{array}{l}\text { n.a. } \\
\text { n.a. }\end{array}$ & n.a. & n.a. & n.a. & n.a. & n.a. & n.a. & $\mathrm{n}$. & n.a. & n.a. & 151 & 140 & 190 & 29 & 115 & 29 & 3060 \\
\hline $33 \mathrm{X}-2,145-150$ & 39.8 & 120.6 & 11.15 & 39.5 & 8.53 & 2.08 & 8.67 & 1.17 & 6.78 & 1.22 & 3.71 & 0.53 & 3.72 & 0.58 & 248 & 1.40 & 1.03 & 0.92 & 96 & 123 & 228 & 37 & 134 & & 3160 \\
\hline${ }^{b} 33 \mathrm{X}-3,100-101$ & n.a. & n.a. & n.a. & n.a. & n.a. & n.a. & n.a. & n.a. & n.a. & n.a. & n.a. & n.a. & n.a. & n.a. & n.a. & n.a. & n.a. & n.a. & 151 & 138 & 237 & 36 & 112 & 23 & 3260 \\
\hline $34 \mathrm{X}-2,145-150$ & 33.4 & 124.2 & 9.91 & 33.1 & 6.66 & 1.64 & 7.80 & 0.88 & 5.23 & 1.06 & 2.97 & 0.42 & 2.90 & 0.43 & 231 & 1.67 & 0.96 & 0.99 & 96 & 126 & 193 & 40 & 143 & 15 & 2390 \\
\hline$b_{42 X-1,47-49}$ & n.a. & n.a. & n.a. & n.a. & n.a. & n.a. & n.a. & n.a. & n.a. & n.a. & n.a. & n.a. & n.a. & n.a. & n.a. & n.a. & n.a. & n.a. & 116 & & 137 & 12 & 57 & 14 & 3150 \\
\hline b $44 \mathrm{X}-1,29-31$ & n.a. & n.a. & n.a. & n.a. & n.a. & n.a. & n.a. & n.a. & n.a. & n.a. & n.a. & n.a. & n.a. & n.a. & n.a. & n.a. & n.a. & n.a. & 92 & 67 & 108 & 13 & 37 & 12 & 1320 \\
\hline$b_{46} \mathrm{X}-1,40-42$ & n.a. & n.a. & n.a. & n.a. & n.a. & n.a. & n.a. & n.a. & n.a. & n.a. & n.a. & n.a. & n.a. & n.a. & n.a. & n.a. & n.a. & n.a. & 116 & 69 & 127 & 16 & 62 & & 1510 \\
\hline b $47 \mathrm{X}-1,107-109$ & n.a. & n.a. & n.a. & n.a. & n.a. & n.a. & n.a. & n.a. & n.a. & n.a. & n.a. & n.a. & n.a. & n.a. & n.a. & n.a. & n.a. & n.a. & 73 & 94 & 130 & 36 & 79 & & 1960 \\
\hline $\mathrm{b}_{48 \mathrm{X}-1,100-102}$ & n.a. & n.a. & n.a. & n.a. & n.a. & n.a. & n.a. & n.a. & n.a. & n.a. & n.a. & n.a. & n.a. & n.a. & n.a. & n.a. & n.a. & n.a. & 60 & 65 & 102 & 11 & 58 & 20 & 1850 \\
\hline
\end{tabular}

Note: Analyses of non-REE trace elements by XRF at X-Ray Assay Laboratories, Don Mills, Ontario, Canada. Missing values < 10-ppm detection limit. n.a. = not analyzed for 

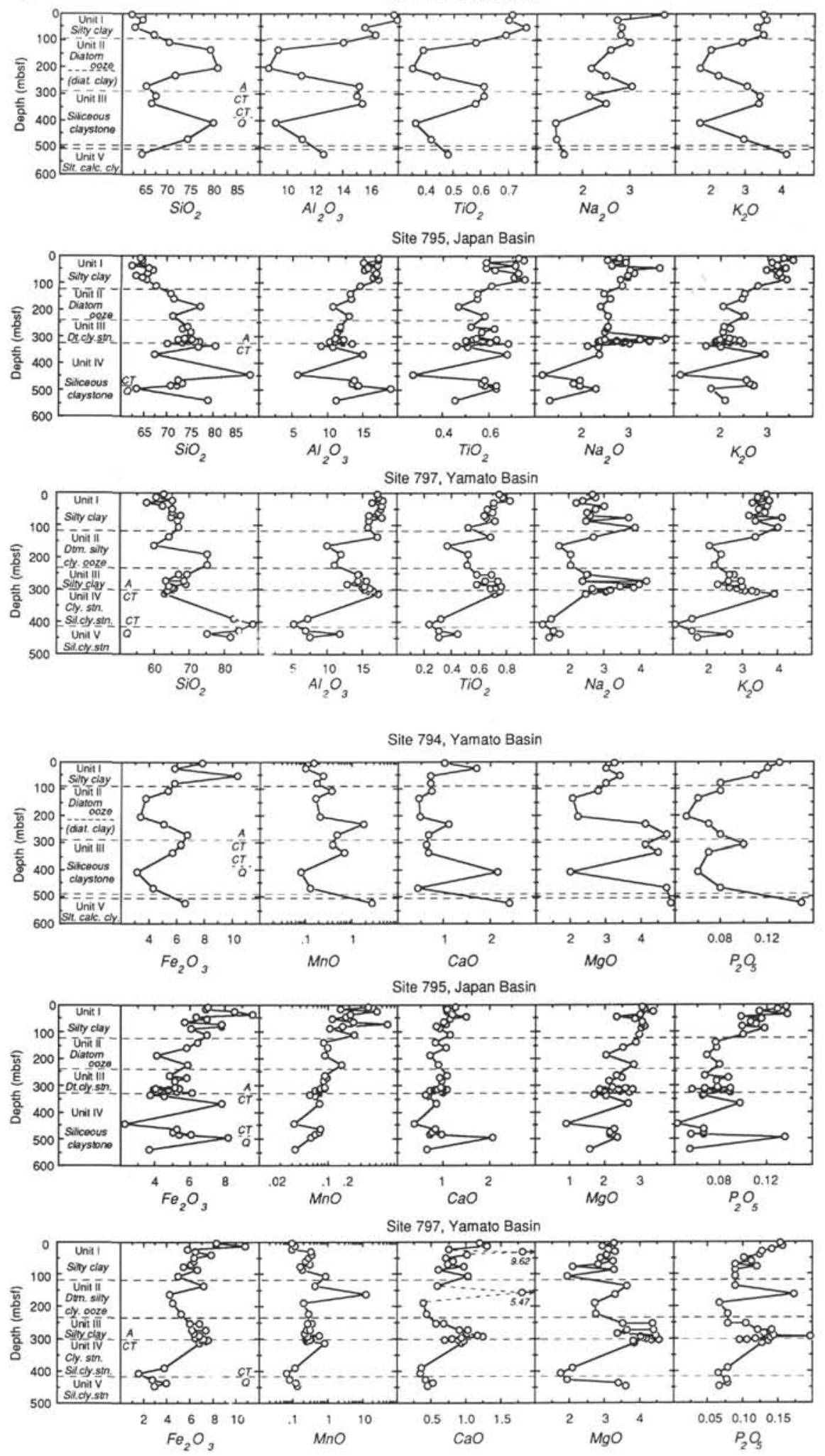

Figure 3. A. Downhole profiles of major element concentrations (wt\%, volatile free) at Sites 794, 795, and 797. The siliceous component within the upper $\sim 300 \mathrm{~m}$ is defined clearest at Site 794. Note the sporadic high concentrations of $\mathrm{SiO}_{2}$ in Unit $\mathrm{IV}$, Site 795. Isolated peaks of $\mathrm{CaO}, \mathrm{MgO}$, and $\mathrm{P}_{2} \mathrm{O}_{5}$ are most likely due to discrete manganese carbonates and stringers (cf. Matsumoto et al., this volume). See text for expanded lithologic descriptions. A, CT, and Q refer to opal-A, opal-CT, and quartz, respectively. Note the change in depth scale for Site 797. B. Al-normalized major element concentration profiles at Sites 794, 795, and 797. Symbols as in Figure 3A. The siliceous interval at Site 794 is clearly delineated by the $\mathrm{Si} / \mathrm{Al}$ peak within Unit II. Note also the large Na/Al increase in Unit II at Site 794 and the greatly enriched $\mathrm{Si} / \mathrm{Al}$ values in Unit $\mathrm{V}$ at Site 797. Note scale changes between sites. 
B
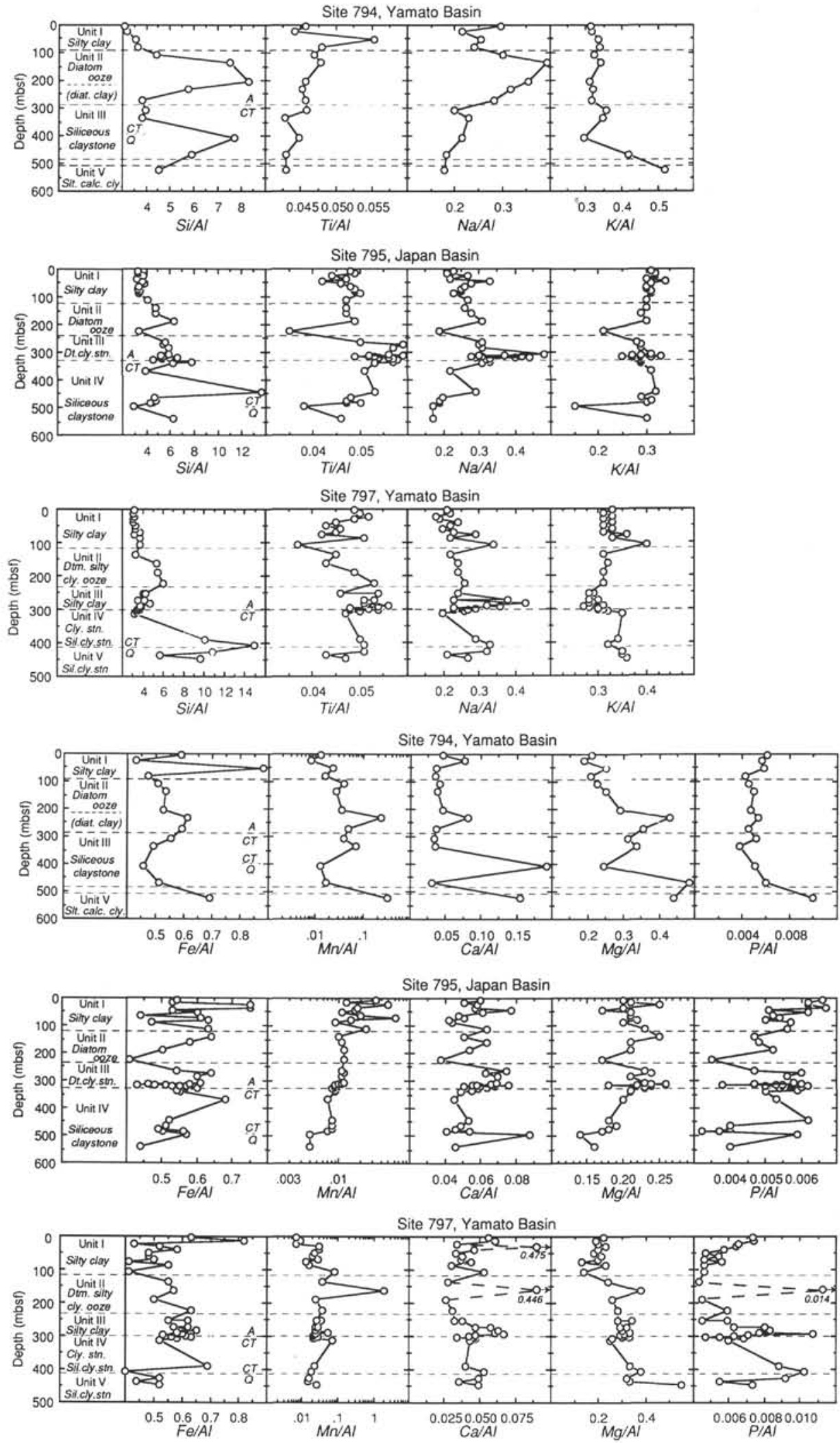

Figure 3 (continued). 

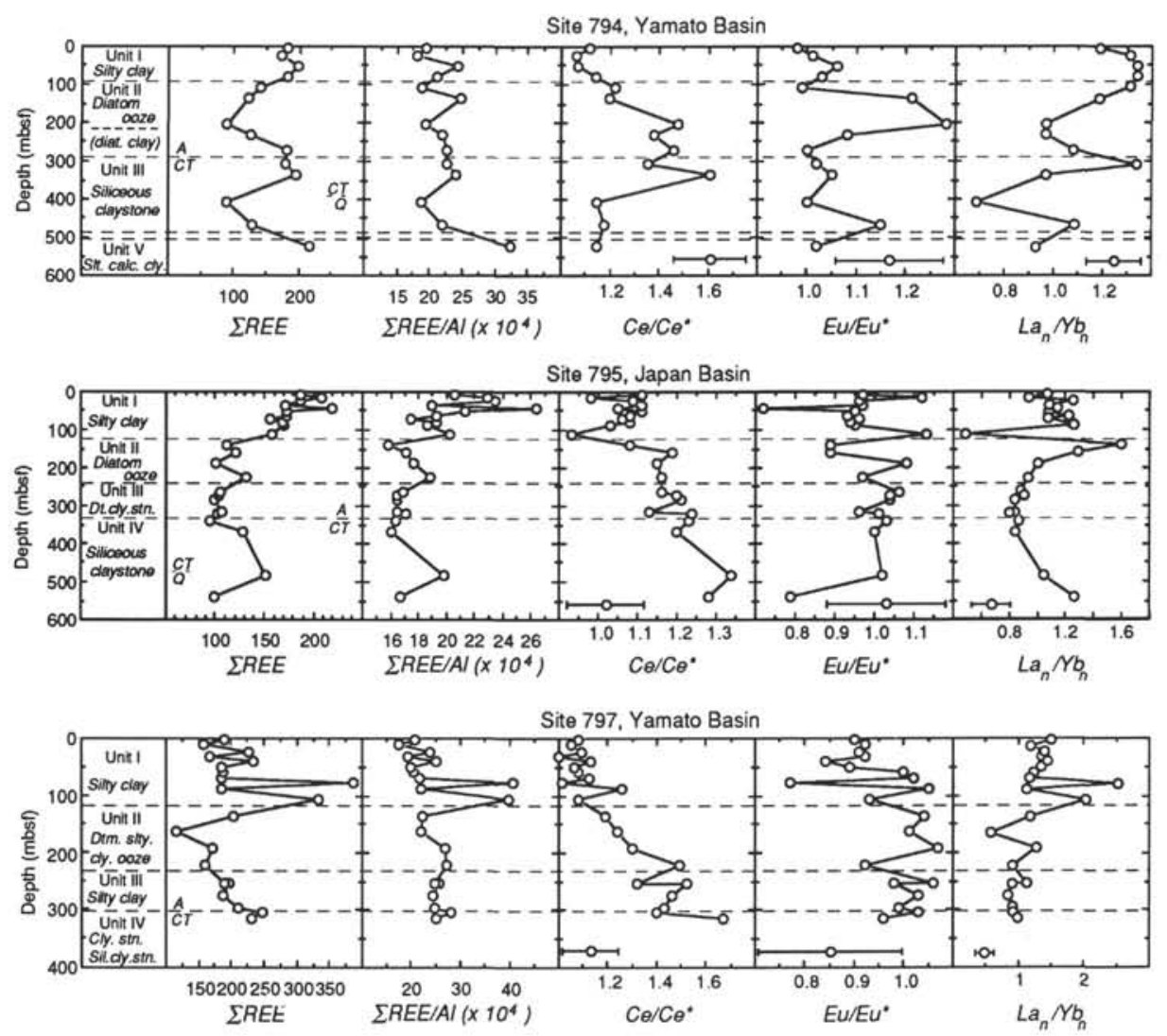

Figure 4. Downhole profiles of REE data at Sites 794, 795, and 797. Symbols as in Figure 3A. All Ce/Ce* values increase essentially monotonically with depth, with the exception of depths $>400 \mathrm{mbsf}$ at Site 794 (see text). Note the large Eu/Eu* increase at Site 794 through Unit II; this accompanies the $\mathrm{Na} / \mathrm{Al}$ increase shown in Figure 3B. EREE enrichments in Unit I at Site 797 are due to the heavy-mineral component. Note the change in depth scale for Site 797. Error bars are of representative maximum error.

cient values suggest a moderate affiliation of $\mathrm{Rb}$ with aluminosilicates and of $\mathrm{Sr}$ with carbonates as well as aluminosilicates (Table 4).

\section{Site 797}

\section{Major Elements}

The $\mathrm{SiO}_{2}$ profile at Site 797 is intermediate in nature to the $\mathrm{SiO}_{2}$ profiles at Site 794 and Site 795 , in that, like at Site $794, \mathrm{SiO}_{2}$ records some relative increase in concentration through the diatom ooze of Unit II (Fig. 3A). As at Site 795, however, the concentration increase at Site 797 is not clearly delineated. $\mathrm{SiO}_{2}$ concentrations through Unit II reach a relative maximum only of $\sim 75 \mathrm{wt} \%$ (dry). The lowest value within the diatomaceous interval $\left(\mathrm{SiO}_{2}=\right.$ $59.8 \mathrm{wt} \%$ at $163.9 \mathrm{mbsf}$ ) reflects dilution by $\mathrm{Mn}, \mathrm{Ca}$, and $\mathrm{P}$, most likely caused by a manganese carbonate nodule or stringer in the particular sample (Fig. 3A). There is no discrete change in $\mathrm{SiO}_{2}$ concentration across the opal-A/opal-CT diagenetic boundary. The high concentrations near the base of Unit IV and into Unit V reflect the increasing proportion of chert and porcellanite at depth. Other major element concentrations respond to the $\mathrm{SiO}_{2}$ profile to varying degrees (Fig. 3B and Table 5). With the exception of the 163.9 mbsf data point (see the preceding), all of the major elements are diluted through the diatomaceous sediments of Unit II and appear to behave relatively similarly downhole. $\mathrm{MgO}$ increases with $\mathrm{SiO}_{2}$ at depth, perhaps reflecting an association with the diagenetic $\mathrm{SiO}_{2}$ phases.

The $\mathrm{Si} / \mathrm{Al}$ profile at Site 797 delineates the siliceous intervals within Unit II as well as the pronounced diagenetic Si enrichment at depth (Fig. 3B). Through Unit II, this $\mathrm{Si} / \mathrm{Al}$ profile is similar to that at Site 794, although Si/Al ratios peak at $\sim 6$ at Site 797 and at $\sim 8$ at Site 794. Most other Al-normalized major element profiles do not present significant lithologic or diagenetic correlations. K/Al, however, seems to increase just below the opal-A/opal-CT transition and through Units IV and V, implying an affiliation with a diagenetically forming phase. $\mathrm{Na} / \mathrm{Al}$ does not show the maximum within the diatomaceous interval that was observed at Site 794, although it does increase in the silty clay of Unit III (Fig. 3B). Ca/Al may also be higher in Unit III.

\section{Rare Earth Elements}

¿REE increases slightly through the silty clays of Unit I (Fig. 4). The two high $\Sigma$ REE ( $385 \mathrm{ppm}$ at $78.3 \mathrm{mbsf} ; 334 \mathrm{ppm}$ at $106.9 \mathrm{mbsf}$ ) each correspond with low $\mathrm{Eu} / \mathrm{Eu}^{*}$ and high $\mathrm{La}_{n} / \mathrm{Yb}_{n}$, as well as with high $\mathrm{Na}_{2} \mathrm{O}, \mathrm{K}_{2} \mathrm{O}, \mathrm{Y}, \mathrm{Zr}$, and $\mathrm{Nb}$, indicating a local heavy-mineral component specific to these samples (although not zircon, as $\mathrm{La}_{n} / \mathrm{Yb}_{n}$ would be low), which does not occur at either Site 794 or Site 795. Although $\Sigma$ REE may be slightly diluted through the uppermost diatomaceous sequences of Unit II, the lowest $\Sigma$ REE at $163.9 \mathrm{mbsf}$ reflects the influence of manganese carbonate, as mentioned previously. $\Sigma$ REE increases continually from this relative minimum at 163.9 mbsf to maximum values of $\sim 240$ ppm just below the opalA/opal-CT diagenetic transition. $\Sigma$ REE is not responding to $\mathrm{SiO}_{2}$ dilution $(r \sim 0)$, and $r<0.45$ between $\Sigma \mathrm{REE}$ and $\mathrm{Al}_{2} \mathrm{O}_{3}$ is the lowest implied aluminosilicate affiliation of all three sites (Table 6). These $r$ values are markedly different from what is observed at either Site 794 
A
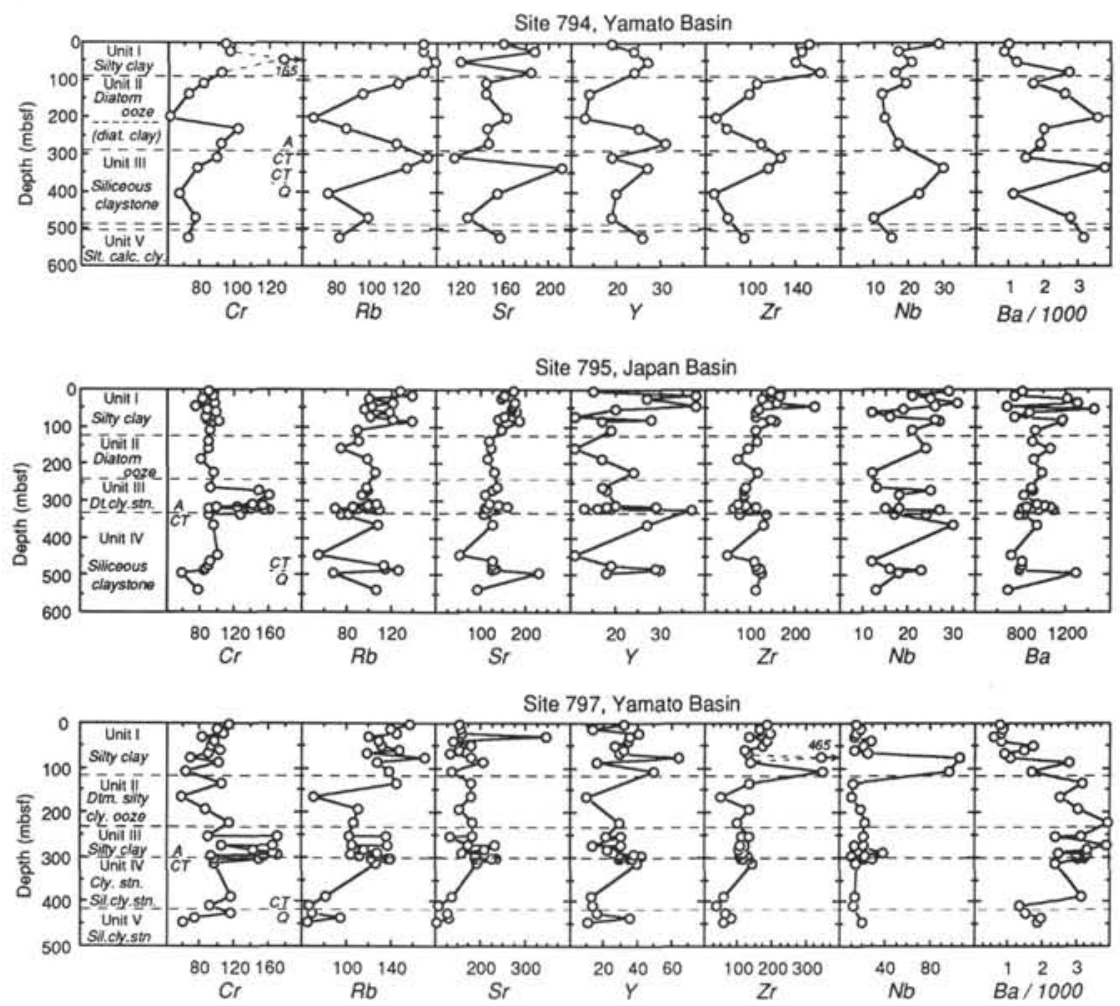

B
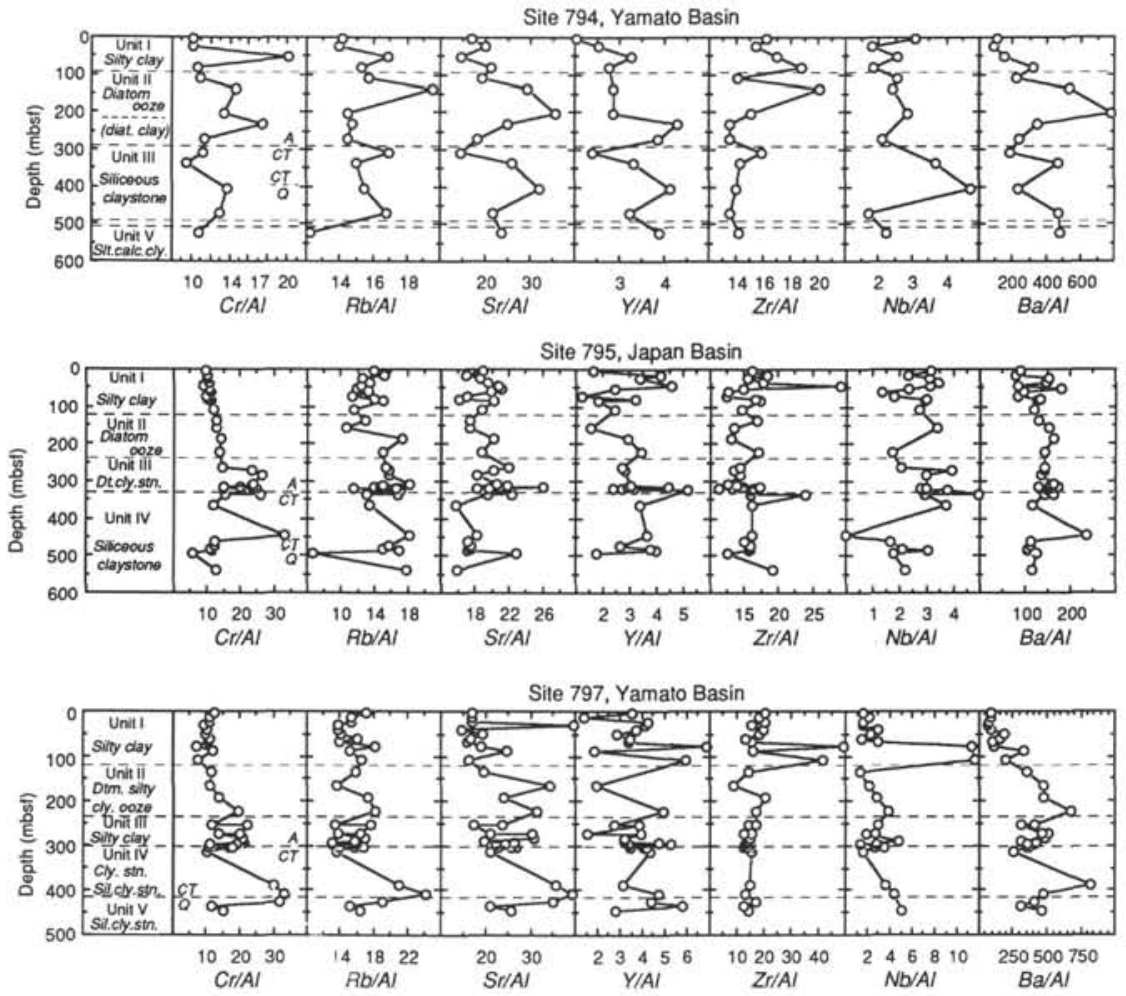

Figure 5. A. Downhole profiles of trace element concentrations (ppm) at Sites 794, 795, and 797. Symbols as in Figure 3A. Note the change in depth scale for Site 797. B. Al-normalized trace element concentration $\left(\times 10^{4}\right)$ profiles at Sites 794, 795, and 797. Symbols as in Figure 3A. Note the change in depth scale for Site 797. 
Table 3. Interelement comparison using correlation coefficient $(r)$ values, Site 794.

\begin{tabular}{|c|c|c|c|c|c|c|c|c|c|c|c|c|c|c|c|c|c|}
\hline & $\mathrm{SiO}_{2}$ & $\mathrm{Al}_{2} \mathrm{O}_{3}$ & $\mathrm{CaO}$ & $\mathrm{MgO}$ & $\mathrm{Na}_{2} \mathrm{O}$ & $\mathrm{K}_{2} \mathrm{O}$ & $\mathrm{Fe}_{2} \mathrm{O}_{3}$ & $\mathrm{MnO}^{\mathrm{a}}$ & $\mathrm{TiO}_{2}$ & $\mathrm{P}_{2} \mathrm{O}_{5}$ & $\mathrm{Cr}$ & $\mathrm{Rb}$ & $\mathrm{Sr}$ & $Y$ & $\mathrm{Zr}$ & $\mathrm{Nb}$ & $\mathrm{Ba}$ \\
\hline $\mathrm{SiO}_{2}$ & 1.00 & & & & & & & & & & & & & & & & \\
\hline $\mathrm{Al}_{2} \mathrm{O}_{3}$ & -0.91 & 1.00 & & & & & & & & & & & & & & & \\
\hline $\mathrm{CaO}$ & & & 1.00 & & & & & & & & & & & & & & \\
\hline $\mathrm{MgO}$ & -0.55 & & & 1.00 & & & & & & & & & & & & & \\
\hline $\mathrm{Na}_{2} \mathrm{O}$ & -0.52 & 0.65 & & & 1.00 & & & & & & & & & & & & \\
\hline $\mathrm{K}_{2} \mathrm{O}$ & -0.90 & 0.80 & & 0.60 & & 1.00 & & & & & & & & & & & \\
\hline $\mathrm{Fe}_{2} \mathrm{O}_{3}$ & -0.87 & 0.72 & & & 0.52 & 0.69 & 1.00 & & & & & & & & & & \\
\hline${ }^{\mathrm{MnO}} \mathrm{O}$ & & & & 0.58 & & & & 1.00 & & & & & & & & & \\
\hline $\mathrm{TiO}_{2}$ & -0.88 & 0.95 & & & 0.69 & 0.73 & 0.84 & & 1.00 & & & & & & & & \\
\hline $\mathrm{P}_{2} \mathrm{O}_{5}^{-}$ & -0.78 & 0.61 & 0.48 & & & 0.83 & 0.68 & & 0.57 & 1.00 & & & & & & & \\
\hline $\mathrm{Cr}$ & -0.58 & 0.50 & & & & & 0.84 & & 0.69 & & 1.00 & & & & & & \\
\hline $\mathrm{Rb}$ & -0.76 & 0.90 & & & 0.63 & 0.66 & 0.71 & & 0.93 & & & 1.00 & & & & & \\
\hline $\mathrm{Sr}$ & & & & & & & & & & & & & 1.00 & & & & \\
\hline $\mathrm{Y}$ & -0.70 & 0.55 & & 0.62 & & 0.56 & 0.57 & 0.52 & 0.53 & & & & & 1.00 & & & \\
\hline $\mathrm{Zr}$ & -0.77 & 0.91 & & & 0.67 & 0.69 & 0.68 & & 0.93 & 0.52 & & & & & 1.00 & & \\
\hline $\mathrm{Nb}$ & & 0.49 & & & & & & & 0.45 & & & & & & & 1.00 & \\
\hline $\mathrm{Ba}$ & & & & & & & & & -0.46 & & & & & & & & 1.00 \\
\hline
\end{tabular}

Note: $-r$ indicates negative correlation. $-0.45<r<0.45$ not shown $(~-95 \%$ confidence interval).

${ }^{2}$ Determined without two nonrepresentative values from 232.5 and $523.7 \mathrm{mbsf}$ (see text and Fig. 3).

Table 4. Interelement comparison using correlation coefficient $(r)$ values, Site 795.

\begin{tabular}{|c|c|c|c|c|c|c|c|c|c|c|c|c|c|c|c|c|c|}
\hline & $\mathrm{SiO}_{2}$ & $\mathrm{Al}_{2} \mathrm{O}_{3}$ & $\mathrm{CaO}$ & $\mathrm{MgO}$ & $\mathrm{Na}_{2} \mathrm{O}$ & $\mathrm{K}_{2} \mathrm{O}$ & $\mathrm{Fe}_{2} \mathrm{O}_{3}$ & $\mathrm{MnO}$ & $\mathrm{TiO}_{2}$ & $\mathrm{P}_{2} \mathrm{O}_{5}$ & $\mathrm{Cr}$ & $\mathrm{Rb}$ & $\mathrm{Sr}$ & Y & $\mathrm{Zr}$ & $\mathrm{Nb}$ & $\mathrm{Ba}$ \\
\hline $\mathrm{SiO}_{2}$ & 1.00 & & & & & & & & & & & & & & & & \\
\hline $\mathrm{Al}_{2} \mathrm{O}_{3}$ & -0.96 & 1.00 & & & & & & & & & & & & & & & \\
\hline $\mathrm{CaO}$ & -0.69 & 0.69 & 1.00 & & & & & & & & & & & & & & \\
\hline $\mathrm{MgO}$ & -0.85 & 0.77 & & 1.00 & & & & & & & & & & & & & \\
\hline $\mathrm{Na}_{2} \mathrm{O}$ & & & & & 1.00 & & & & & & & & & & & & \\
\hline $\mathrm{K}_{2} \mathrm{O}$ & -0.86 & 0.83 & & 0.76 & & 1.00 & & & & & & & & & & & \\
\hline $\mathrm{Fe}_{2} \mathrm{O}_{3}$ & -0.92 & 0.85 & 0.62 & 0.77 & & 0.73 & 1.00 & & & & & & & & & & \\
\hline $\mathrm{MnO}$ & -0.57 & 0.49 & & 0.57 & & 0.56 & 0.56 & 1.00 & & & & & & & & & \\
\hline $\mathrm{TiO}_{2}$ & -0.89 & 0.88 & 0.49 & 0.84 & & 0.81 & 0.77 & 0.45 & 1.00 & & & & & & & & \\
\hline $\mathrm{P}_{2} \mathrm{O}_{5}^{2}$ & -0.87 & 0.82 & 0.71 & 0.71 & & 0.69 & 0.83 & 0.53 & 0.77 & 1.00 & & & & & & & \\
\hline $\mathrm{Cr}$ & & & & & & & & & & & 1.00 & & & & & & \\
\hline $\mathrm{Rb}$ & -0.61 & 0.72 & & 0.49 & & 0.73 & & & 0.73 & 0.62 & & 1.00 & & & & & \\
\hline $\mathrm{Sr}$ & -0.83 & 0.86 & 0.86 & 0.62 & 0.46 & 0.59 & 0.69 & & 0.71 & 0.83 & & 0.62 & 1.00 & & & & \\
\hline Y & & & & & & 0.46 & & & & & & 0.48 & & 1.00 & & & \\
\hline $\mathrm{Zr}$ & -0.69 & 0.71 & 0.48 & 0.51 & & 0.75 & 0.59 & & 0.57 & 0.56 & -0.47 & 0.46 & 0.58 & & 1.00 & & \\
\hline $\mathrm{Nb}$ & & & & & & & 0.52 & & & 0.45 & & & & & & 1.00 & \\
\hline $\mathrm{Ba}$ & -0.47 & & & 0.46 & & & 0.56 & & & 0.53 & & & 0.54 & & & & 1.00 \\
\hline
\end{tabular}

Note: $-r$ indicates negative correlation. $-0.45<r<0.45$ not shown $\left(-95 \%\right.$ confidence interval). 2 REE vs. accumulation rate $\left(g / \mathrm{cm}^{2} / \mathrm{k} . \mathrm{y}\right.$. $)=-0.50$.

Table 5. Interelement comparison using correlation coefficient $(r)$ values, Site 797.

\begin{tabular}{|c|c|c|c|c|c|c|c|c|c|c|c|c|c|c|c|c|c|}
\hline & $\mathrm{SiO}_{2}$ & $\mathrm{Al}_{2} \mathrm{O}_{3}$ & $\mathrm{CaO}$ & $\mathrm{MgO}$ & $\mathrm{Na}_{2} \mathrm{O}$ & $\mathrm{K}_{2} \mathrm{O}$ & $\mathrm{Fe}_{2} \mathrm{O}_{3}$ & $\mathrm{MnO}$ & $\mathrm{TiO}_{2}$ & $\mathrm{P}_{2} \mathrm{O}_{5}$ & $\mathrm{Cr}$ & $\mathrm{Rb}$ & $\mathrm{Sr}$ & $\mathrm{Y}$ & $\mathrm{Zr}$ & $\mathrm{Nb}$ & $\mathrm{Ba}$ \\
\hline $\mathrm{SiO}_{2}$ & 1.00 & & & & & & & & & & & & & & & & \\
\hline $\mathrm{Al}_{2} \mathrm{O}_{3}$ & -0.87 & 1.00 & & & & & & & & & & & & & & & \\
\hline $\mathrm{CaO}$ & -0.77 & 0.67 & 1.00 & & & & & & & & & & & & & & \\
\hline $\mathrm{MgO}$ & -0.52 & & & 1.00 & & & & & & & & & & & & & \\
\hline $\mathrm{Na}_{2} \mathrm{O}$ & -0.59 & 0.64 & 0.74 & & 1.00 & & & & & & & & & & & & \\
\hline $\mathrm{K}_{2} \mathrm{O}$ & -0.78 & 0.94 & 0.60 & & 0.57 & 1.00 & & & & & & & & & & & \\
\hline $\mathrm{Fe}_{2} \mathrm{O}_{3}$ & -0.81 & 0.82 & 0.74 & 0.53 & 0.59 & 0.68 & 1.00 & & & & & & & & & & \\
\hline $\mathrm{MnO}$ & & & & & & 0.45 & & 1.00 & & & & & & & & & \\
\hline $\mathrm{TiO}_{2}$ & -0.83 & 0.93 & 0.70 & 0.58 & 0.64 & 0.80 & 0.88 & & 1.00 & & & & & & & & \\
\hline $\mathrm{P}_{2} \mathrm{O}_{5}^{2}$ & -0.73 & 0.66 & 0.89 & & 0.53 & 0.57 & 0.73 & & 0.76 & 1.00 & & & & & & & \\
\hline $\mathrm{Cr}$ & & & & 0.56 & 0.48 & & & & & & 1.00 & & & & & & \\
\hline $\mathrm{Rb}$ & -0.71 & 0.89 & 0.59 & & 0.66 & 0.89 & 0.73 & & 0.84 & 0.61 & & 1.00 & & & & & \\
\hline $\mathrm{Sr}$ & -0.54 & 0.47 & & 0.49 & 0.46 & & 0.48 & & 0.54 & & & & 1.00 & & & & \\
\hline Y & & 0.59 & & & 0.45 & 0.69 & & & 0.45 & & & 0.62 & & 1.00 & & & \\
\hline $\mathrm{Zr}$ & -0.64 & 0.86 & & & & 0.86 & 0.73 & & 0.80 & 0.59 & & 0.79 & & 0.52 & 1.00 & & \\
\hline $\mathrm{Nb}$ & & & & & 0.56 & & & & & & 0.57 & & & & & 1.00 & \\
\hline $\mathrm{Ba}$ & & & & & & & & & & & 0.45 & & 0.62 & & & & 1.00 \\
\hline
\end{tabular}

Note: $-r$ indicates negative correlation. $-0.45<r<0.45$ not shown ( $~ 95 \%$ confidence interval). Determined without nonrepresentative values for MnO (163.9 mbsf), $\mathrm{CaO}(30.9,163.9 \mathrm{mbsf}), \mathrm{P}_{2} \mathrm{O}_{5}(163.9,294.4 \mathrm{mbsf}), \mathrm{Zr}-\mathrm{Nb}(78.3,163.9 \mathrm{mbsf})$, and $\mathrm{Sr}(30.9 \mathrm{mbsf})$ (see text and appropriate figures). 
Table 6. Correlation coefficients $(r)$ for REE data from Leg 127 squeeze-cake residues.

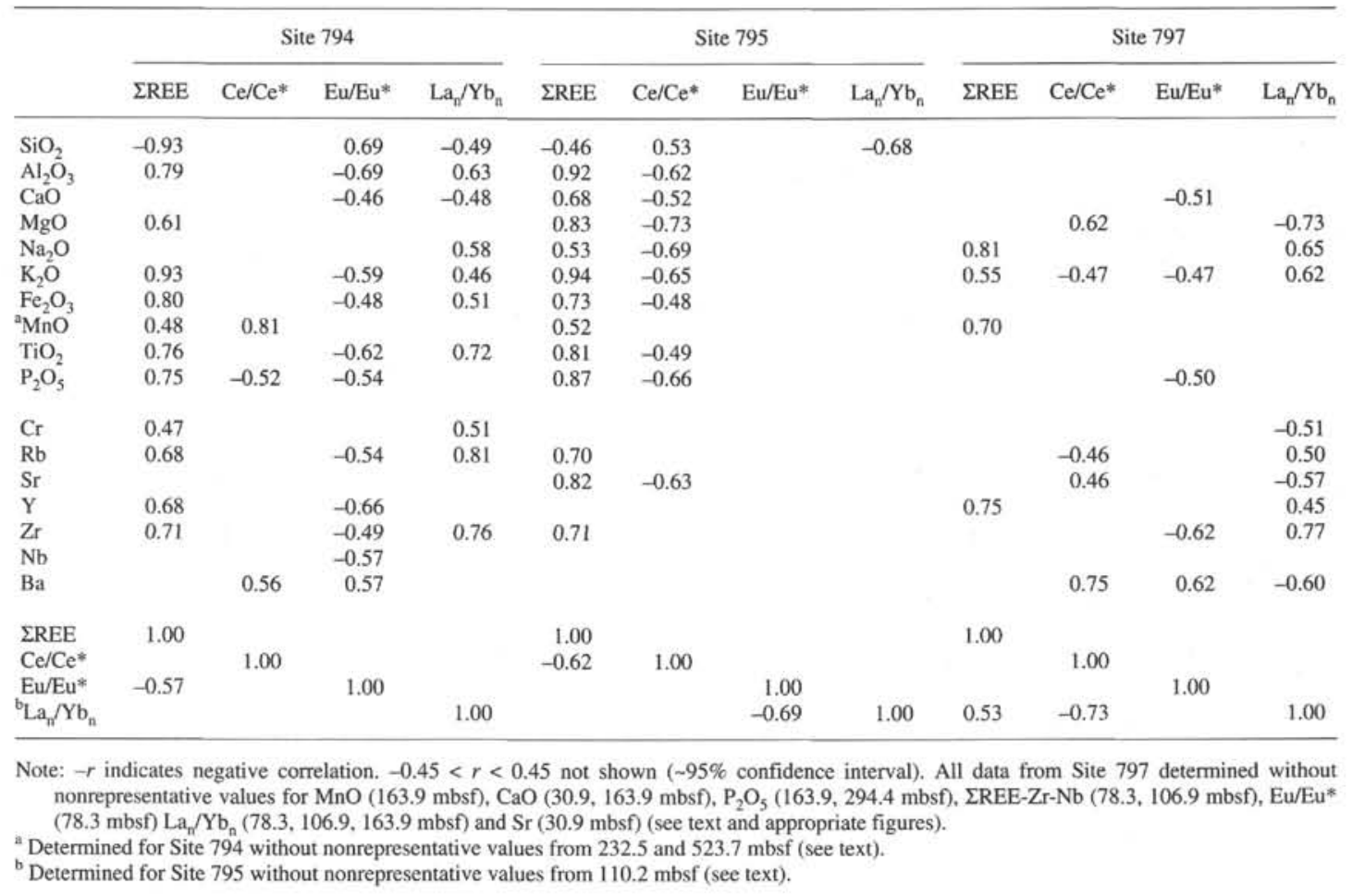

or Site 795, and suggest an influence on EREE of an additional sedimentary component other than the siliceous or aluminosilicate fraction. Note also that these $r$ values are calculated while excluding the anomalously high $\Sigma R E E$ relating to high $\mathrm{Y}, \mathrm{Zr}$, and $\mathrm{Nb}$ near the base of Unit I. In general, $\Sigma$ REE is correlated rather weakly at Site 797 compared with the other two sites; the only $r>0.8$ is with $\mathrm{Na}_{2} \mathrm{O}$ $(r=0.81)$, with other associations more weakly implied between $\mathrm{MnO}, \mathrm{K}_{2} \mathrm{O}$, and $\mathrm{Y}$ (Table 6).

$\mathrm{Ce} / \mathrm{Ce}^{*}$ values average $1.09 \pm 0.07$ through the silty clay of Unit $\mathrm{I}$, before increasing essentially monotonically to a maximum of 1.67 within Unit IV (Fig. 4). Eu/Eu* values average $0.90 \pm 0.03$ through the upper $49.8 \mathrm{~m}$ of Subunit IA, before increasing to slightly greater values $(\sim 1.01$ $\pm 0.05)$ downhole to Subunit IVA. The low value $\left(\mathrm{Eu} / \mathrm{Eu}^{*}=0.77\right)$ at 78.3 mbsf occurs in one of the samples with a potential heavy-mineral dominance (see the preceding). $\mathrm{La}_{\mathrm{n}} / \mathrm{Yb}_{\mathrm{n}}$ decreases consistently downhole from near-surface values of $\sim 1.4$ to values within Unit IV ranging from $\sim 0.9$ to 1 . The relatively high $\mathrm{La}_{n} / \mathrm{Yb}_{\mathrm{n}}=2.53(78.3 \mathrm{mbs})$ and $=2.04$ (106.9 mbsf) within Unit $\mathrm{I}$ is coincident with high $\Sigma \mathrm{REE}, \mathrm{Na} / \mathrm{Al}, \mathrm{Y} / \mathrm{Al}$, and $\mathrm{Zr} / \mathrm{Al}$, as well as with low $\mathrm{Eu} / \mathrm{Eu}$, as discussed previously. The low $\mathrm{La}_{\mathrm{n}} / \mathrm{Yb}_{\mathrm{n}}=0.57$ at $163.9 \mathrm{mbsf}$ corresponds with low $\Sigma \mathrm{REE}$ as well as with high $\mathrm{MnO}, \mathrm{CaO}$, and $\mathrm{P}_{2} \mathrm{O}_{5}$ and suggests REE fractionation into a manganese carbonate or phosphatic nodule or stringer.

\section{Trace Elements}

Trace element profiles at Site 797 in general show little variation through the silty clays of Unit I and the diatomaceous sequence of Unit II (Fig. 5A). The Y, Zr, and $\mathrm{Nb}$ peaks within Unit I are due to the heavy-mineral input discussed previously. $\mathrm{Cr}, \mathrm{Rb}$, and perhaps $\mathrm{Sr}$ increase into Unit III; as at Site 795, Cr is enriched greatly, yet shows no strong interelement correlation (Table 5). All elements, except for $\mathrm{Nb}$, decrease in concentration below the opal-A/opal-CT transition through Unit IV. Al-normalized trace element profiles (Fig. 5B) indicate that most trace elements are affiliated with aluminosilicate phases, although some profiles (e.g., $\mathrm{Sr} / \mathrm{Al}$ ) increase at depth.

\section{REES IN JAPAN SEA SEDIMENTS}

REE total concentrations and relative fractionations are potentially responding to the combined influences of (1) paleoceanographic and paleogeographic variation, (2) sediment lithology, and (3) diagenetic modification. The relative importance of each of these influences in controlling the REE composition of Japan Sea sediment at each site is synthesized in this section. Overall, the REEs are associated predominantly with the detrital fraction, which is diluted by biogenic input that is driven by productivity in the overlying water column. Due to the fact that the Japan Sea is an enclosed marginal basin dominated by terrigenous and biogenic sources, REE scavenging by metalliferous components is unimportant, although the process is a major influence elsewhere in marine sediment (e.g., Ruhlin and Owen, 1986; Murray et al., 1991).

Accordingly, paleogeographic position with respect to detrital and productivity inputs is the most important controlling influence on $\Sigma$ REE concentrations within Japan Sea sediments (Fig. 6). $\mathrm{Ce} / \mathrm{Ce}$ * does not respond to these inputs, as $\mathrm{Ce} / \mathrm{Ce} *$ does not correlate with $\mathrm{SiO}_{2}$ or $\mathrm{Al}_{2} \mathrm{O}_{3}$ to any significant degree, nor does the $\mathrm{Ce} / \mathrm{Ce} *$ profile systematically change through diatomaceous intervals. $\Sigma$ REE at both Sites 794 and 795 is controlled by terrigenous input from the nearby Japan Arc; the relatively high correlations of $\Sigma \mathrm{REE}$ with $\mathrm{Al}_{2} \mathrm{O}_{3}$ and $\mathrm{K}_{2} \mathrm{O}$ suggest that most REEs are associated with clay minerals. Major element ratios (e.g., $\mathrm{P}_{2} \mathrm{O}_{5} / \mathrm{Al}_{2} \mathrm{O}_{3}$ ) are also similar to that of average shale. At Site 794, a pronounced $\mathrm{Eu} / \mathrm{Eu}^{*}$ increase through the diatomaceous Unit II may indicate an Eu-rich siliceous input or, alternatively, an additional feldspar contribution. In contrast to Sites 794 and 795 , $\Sigma$ REE at Site 797 correlates poorly with $\mathrm{Al}_{2} \mathrm{O}_{3}$ and the other major elements, and may be controlled locally and sporadically by a detrital heavy-mineral association. Such heavy minerals most likely would have originated from the rifted continental fragment composing the Yamato Rise, located nearby to the west (Fig. 1). Although there clearly is detrital input from the Yamato Rise beginning in the late Pliocene (Fig. 2), earlier inputs may be masked by diagenetic 


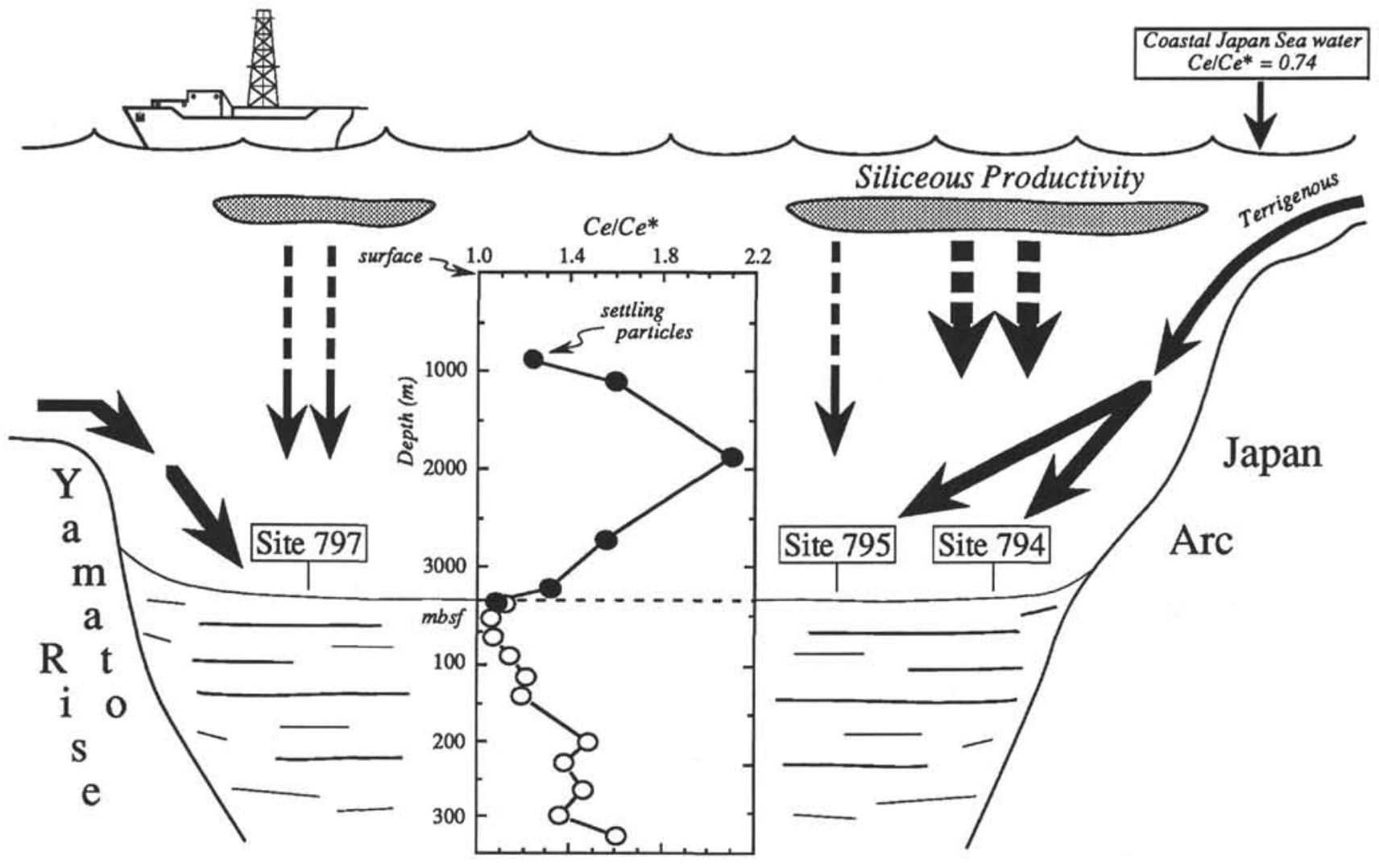

Figure 6. Schematic diagram summarizing processes that control $\Sigma R E E$ and Ce/Ce* at Sites 794, 795, and 797. Sites are positioned according to their paleogeographic position relative to the detrital inputs from the Japan Arc and Yamato Rise as well as suggesting the relative significance of biogenic input from overlying water; sites are not positioned according to their actual location (Fig. 1). Note the change in scale between depth in seawater and sub-bottom depth. Coastal Japan Sea water data from Tanaka et al. (1990; Fig. 1), settling particle data from Masuzawa and Koyama (1989; Fig. 1), sediment data from this work (Site 794). Site 794 is heavily influenced by terrigenous input from the Japan Arc as well as by the biogenic component from the highly productive overlying water. $\mathrm{REEE}$ concentrations at Site 797 suggest input from the Yamato Rise. At Sites 795 and 797 , the dashed line of productivity indicates the secondary role of siliceous input in controlling the EREE concentrations in the sediment. All three sites possess similar, diagenetically influenced, downhole $\mathrm{Ce} / \mathrm{Ce}$ * profiles; see the text for discussion of diagenetic mechanisms affecting the final preserved $\mathrm{Ce} / \mathrm{Ce}$ * of Japan Sea sediment.

alteration. There is little correlation between $\Sigma$ REE and accumulation rate at any site (see discussion in Ruhlin and Owen, 1986; Murray et al., 1991), most likely because the accumulation rates are relatively similar and high throughout the Japan Sea (20-77 m/m.y.; Tamaki, Pisciotto, Allan, et al., 1990).

The detrital inputs (from the Japan Arc for Sites 794 and 795, from the Yamato Rise for Site 797) are diluted to varying degrees by the biogenic input from the overlying seawater. $\mathrm{R}$ REE values are most influenced by biogenic $\mathrm{SiO}_{2}$ at Site 794, consistent with the location of Site 794 in the eastern portion of the Japan Sea, where upwelling and biogenic productivity were perhaps greatest. $\Sigma$ REE values at Sites 795 and 797 also are diluted by the biogenic input, although not to the same extreme as $\Sigma$ REE at Site 794. The two Yamato Basin sites reflect greater siliceous input than Site 795 in the Japan Basin.

REE abundances and relative fractionations within Japan Sea sediment do not record any basinwide paleoceanographic change. The consistent downhole increase in $\mathrm{Ce} / \mathrm{Ce}{ }^{*}$ at each site preserves diagenetic, not paleoceanographic, processes. Below $400 \mathrm{mbsf}$ at Site $794, \mathrm{Ce} / \mathrm{Ce} *$ seems to decrease due to effects of $\mathrm{SiO}_{2}$ diagenesis, as discussed previously. Although previous workers have related $\mathrm{Ce} / \mathrm{Ce} *$ values in sediments to the redox state of the overlying waters (e.g., Liu et al., 1988; see discussion of German and Elderfield, 1990a), there is no independent geologic, stratigraphic, paleontologic, or chemical data to suggest the existence of a monotonic and progressive oxygenation of the Japan Sea which would be required to produce the $\mathrm{Ce} / \mathrm{Ce} *$ profile (Tamaki, Pisciotto, Allan, et al., 1990). In fact, as described earlier, bottom-water conditions ranged from oxic to dysaerobic throughout the Miocene, were in general well oxygenated during the late Miocene to Pliocene, and have recently included periods of anoxic deep water None of these large-scale fluctuations in the oxygenation of bottom waters are recorded by $\mathrm{Ce} / \mathrm{Ce} *$ at any Leg 127 site. Indeed, because $\mathrm{Ce}$ reduction can occur under suboxic (not completely anoxic) conditions (e.g., German and Elderfield, 1990b), the independently documented variations of the Japan Sea dissolved oxygen should result in many oscillations of $\mathrm{Ce} / \mathrm{Ce}$ * values, were $\mathrm{Ce} / \mathrm{Ce}$ * in sediment responding faithfully to variations in the overlying water's oxygenation state. Furthermore, a comparison of downhole $\mathrm{Ce} / \mathrm{Ce}$ * profiles between Sites 794 and 797 (Fig. 7), which should record the same paleoceanographic signature because they are located within the same basin (Fig. 1), indicates that $\mathrm{Ce} / \mathrm{Ce}$ * correlates slightly better with depth than with age.

The consistent downhole increase of $\mathrm{Ce} / \mathrm{Ce}$ * instead is explained best by diagenetic fractionations. Masuzawa and Koyama (1989) measured large positive $\mathrm{Ce}$ anomalies $(\sim 1.56 \pm 0.34)$ for settling particles of undifferentiated composition in the Japan Sea and concluded that Ce is preferentially removed from Japan Sea waters, in association with Mn. This Ce is most likely Ce(IV), because Ce(III) behaves similarly to the other trivalent REEs. Based on the less extreme positive $\mathrm{Ce}$ anomalies 

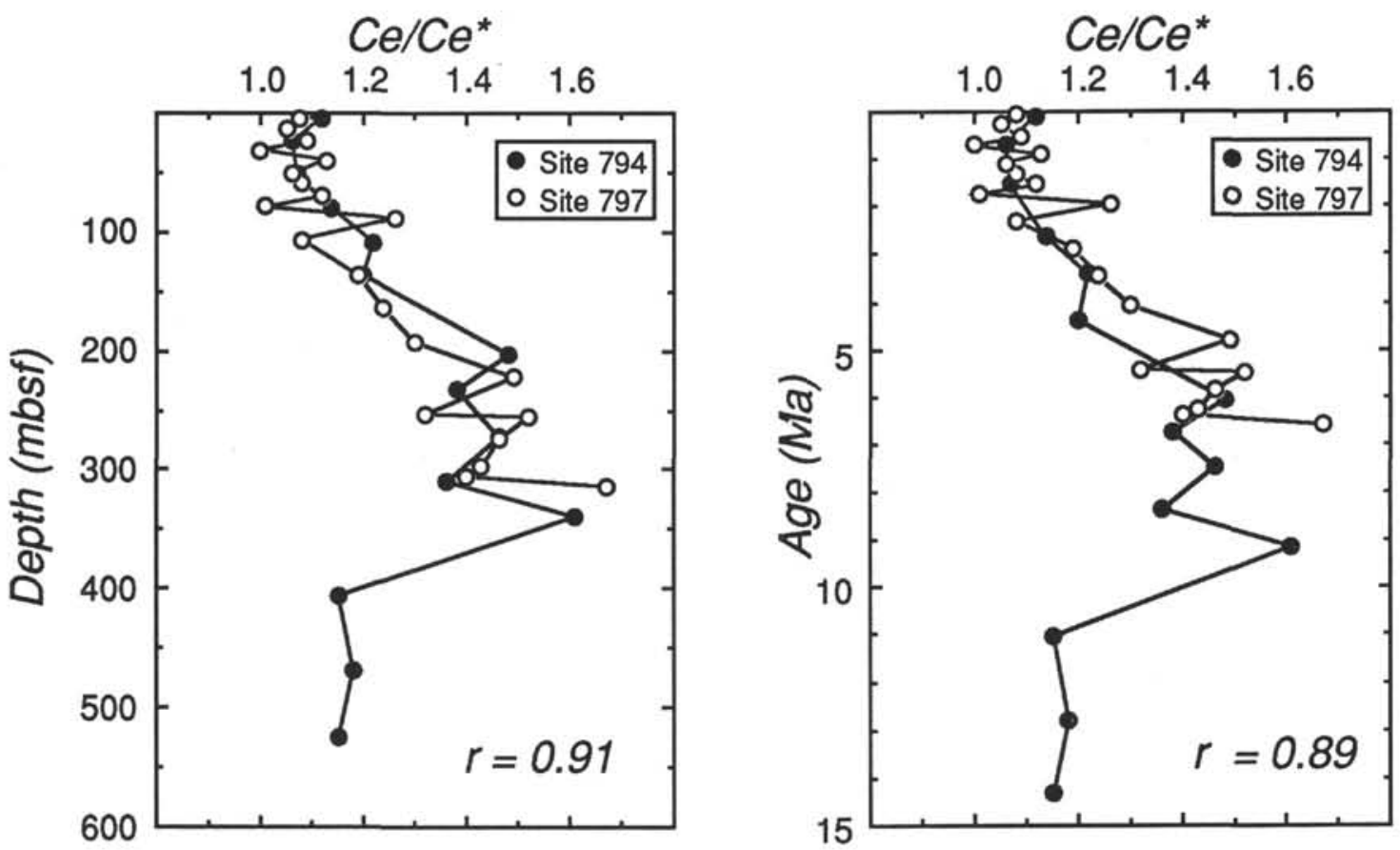

Figure 7. Profiles of $\mathrm{Ce} / \mathrm{Ce} *$ at Sites 794 and 797 plotted downhole vs. depth and age. Note the overlapping plots of the two sites and the slightly higher correlation coefficient when plotted vs. depth; better correlations would be expected vs. age, not depth, were $\mathrm{Ce} / \mathrm{Ce}$ * responding to paleoceanographic variations in the overlying water.

from the surface sediment $\left(\mathrm{Ce} / \mathrm{Ce}^{*}=1.07\right)$ than in the settling particles, Masuzawa and Koyama (1989) further suggested that the Ce-bearing Mn(IV) oxide phases are liberated in conjunction with the decomposition of organic material at or near the seafloor. By monitoring both the bulk flux and $\mathrm{Al}$ flux near the seafloor they were able to rule out significant resuspension of bottom sediment in their particulate samples (Masuzawa and Koyama, 1989). We note further that much of the Ce liberation must be occurring while particles are relatively high in the water column, as shown by the substantial decrease in particulate $\mathrm{Ce} / \mathrm{Ce} *$ below $1870-\mathrm{m}$ water depth (Fig. 6). The fact that $\mathrm{Ce}$ is cycling actively in the water column suggests that $\mathrm{Ce}$ may also be relatively labile during diagenetic reactions within the sediment. Indeed, by definition, the increasing $\mathrm{Ce} / \mathrm{Ce}$ * profile through at least the upper $350 \mathrm{~m}$ of each site indicates that with continued burial Ce concentrations are increasing in the sediment, relative to concentrations of the neighboring trivalent LREEs. Whether this relative $\mathrm{Ce}$ increase is due to transfer of $\mathrm{Ce}$ from interstitial waters to sediment or to removal of other LREEs from sediment remains to be seen; examination of the $\mathrm{La}_{n} / \mathrm{Yb}_{\mathrm{n}}$ ratio may help differentiate between the two processes. The following two paragraphs address this topic.

$\mathrm{La}_{\mathrm{n}} / \mathrm{Yb}_{\mathrm{n}}$ values are mostly within the range of postulated average terrigenous input ( 1.0-1.3; Sholkovitz, 1990; Condie, 1991), excluding the obvious nonrepresentative values discussed previously. Other subtle yet systematic deviations from this average are apparent at all three sites and, with the notable exception of Unit IV at Site 795, $\mathrm{La}_{\mathrm{n}} / \mathrm{Yb}_{\mathrm{n}}$ tends to increase with depth. These trends potentially reflect one or more of the following testable hypotheses: (1) variation in REE fractionation during adsorption from seawater, (2) changes in REE input associated with changes in sediment sources to the basin, or (3) diagenetic remobilization and exchange with interstitial water. Mechanism (1) is improbable, because REE fractionation from seawater would preferentially remove LREEs from seawater and add them to sediment, thereby increasing — not decreasing —-sedimentary $\mathrm{La}_{\mathrm{n}} / \mathrm{Yb}_{\mathrm{n}}$ values. Mechanism (2) may explain some of the variation, although its impact is unlikely to be large, given the relative uniformity of mixed terrestrial sediments like these of similar age and tectonic environment (e.g., Taylor and McLennan, 1985) and that there are only slight differences in post middle Miocene clay mineralogy throughout these sites, as discussed previously (Fagel et al., 1991). $\mathrm{La}_{\mathrm{n}} / \mathrm{Yb}_{\mathrm{n}}$ values may, however, tend to decrease through the diatomaceous sequences, which may reflect primary compositional or adsorptive differences between biogenic and terrigenous particles. Mechanism (3) would require either the successive loss of LREEs from sediment to interstitial water, which seemingly contradicts the $\mathrm{Ce} / \mathrm{Ce} *$ increase discussed previously, or the transfer of HREEs from sediment to interstitial water, which also is improbable, given the relatively restricted behavior of HREEs in other diagenetic and marine environments (e.g., Fleet, 1984; Sholkovitz et al., 1989). If diagenetic remobilization of LREEs actually is occurring, however, transfer of LREEs from sediment to interstitial water must be occurring to LREEs with the exception of $\mathrm{Ce}$, as $\mathrm{Ce} / \mathrm{Ce} *$ increases with depth. This would require $\mathrm{Ce}$, behaving anomalously due to its higher oxidation state, to be retained on the sediment while the remaining LREEs are transferred to interstitial waters.

Although $\mathrm{Ce} / \mathrm{Ce}$ * does not correlate well with $\mathrm{La}_{\mathrm{n}} / \mathrm{Yb}_{\mathrm{n}}$ for all points at a given site (with the exception of Site 797; Table 5), there nevertheless may be a genetic relationship between the loss of LREEs (except for $\mathrm{Ce}$ ) from sediment and development of a positive $\mathrm{Ce}$ anomaly. It is necessary to evaluate whether the hypothesized LREE transfer from sediment to the interstitial water could cause or accentuate the downhole $\mathrm{Ce} / \mathrm{Ce}$ * increase observed at all sites. Considering first Site 797 because the $\mathrm{La}_{n} / \mathrm{Yb}_{n}$ and $\mathrm{Ce} / \mathrm{Ce}$ * profiles are nearly linear through the entire sequence and it is the only site with a suggested correlation between $\mathrm{La}_{\mathrm{n}} / \mathrm{Yb}_{\mathrm{n}}$ and $\mathrm{Ce} / \mathrm{Ce} *$ (Table 6), the consistent decrease from near-surface $\mathrm{La}_{n} / \mathrm{Yb}_{\mathrm{n}}$ values of $\sim 1.40$ to $\mathrm{La}_{\mathrm{n}} / \mathrm{Yb}_{\mathrm{n}} \sim 0.95$ at depth requires a $32 \%$ loss of $\mathrm{La}$, with respect to $\mathrm{Yb}$. $\mathrm{Ce}^{*}$ would also decrease by $32 \%$, resulting in an overall $\sim 50 \%$ increase in the calculated $\mathrm{Ce} / \mathrm{Ce} *$. At Site 797 , then, if all $\mathrm{Ce}$ is retained on sediment, loss of LREEs with depth would predict a $\mathrm{Ce} / \mathrm{Ce} *$ change from $\sim 1.1$ to $\sim 1.7$. This predicted value agrees well with the observed profile at Site 797 , where $\mathrm{Ce} / \mathrm{Ce} *$ reaches maximum values of $\sim 1.67$ at depth. The data therefore are consistent with 
sympathetic generation of a positive $\mathrm{Ce}$ anomaly due to LREE transfer from sediment to interstitial water, with $\mathrm{Ce}$ (IV) retained by the sediment. At Site 794 (0-300 mbsf, over which Ce/Ce* increases smoothly), the predicted $\mathrm{Ce} / \mathrm{Ce}^{*}$ due to LREE loss is $\sim 1.4$, again agreeing well with the observed $\mathrm{Ce} / \mathrm{Ce} *$ of $\sim 1.4$. At Site 795 (using $\mathrm{La}_{n} / \mathrm{Yb}_{\mathrm{n}}$ through Unit II and Unit III because $\mathrm{Ce} / \mathrm{Ce} *$ is relatively constant within Unit I), the calculations predict an $\sim 70 \%$ increase in $\mathrm{Ce} / \mathrm{Ce}^{*}$, more than enough to account for the observed $\mathrm{Ce} / \mathrm{Ce} *$ change of $\sim 20 \%$ through the same interval. The increasing $\mathrm{La}_{\mathrm{n}} / \mathrm{Yb}_{\mathrm{n}}$ through Unit $\mathrm{I}$, however, is not paralleled by a $\mathrm{Ce} / \mathrm{Ce} *$ change, nor is the increasing $\mathrm{La}_{\mathrm{n}} / \mathrm{Yb}_{\mathrm{n}}$ through Unit IV, indicating that at Site 795 there may not be a causal link between LREE behavior and downhole development of the positive $\mathrm{Ce}$ anomaly, and that other processes seem to be masking LREE behavior. Considering all sites, then, at Sites 794 and 797 (both in the Yamato Basin) there may be a genetic relationship between LREE loss and generation of a positive $\mathrm{Ce}$ anomaly, whereas at Site 795 (Japan Basin) the exact relationship between $\mathrm{LREE}$ behavior and $\mathrm{Ce} / \mathrm{Ce}$ * remains unclear. This may reflect fundamental contrasts between sedimentation in the two basins (Fig. 1), with the Yamato Basin sediments in general recording a greater influence by biogenic input. Overall, the evidence strongly suggests that the consistent downhole increase in $\mathrm{Ce} / \mathrm{Ce} *$ may be a passive response to LREE loss and need not involve significant remobilization of $\mathrm{Ce}$. The contrast between the LREE transfer from sediment to interstitial water in the Japan Sea and the previous observations documenting LREE uptake by sediment from interstitial water in estuaries (e.g., Sholkovitz et al., 1989) probably reflects the major differences between the deep Japan Sea environment and the shallow estuarine systems; these contrasts include, but are not limited to, sedimentation rate, age of burial and duration of diagenetic reactions recorded by sediment/interstitial water, depth of profile, and organic matter content. Note also that the diagenetic processes documented in the recent and shallowly buried estuaries (Sholkovitz et al., 1989) are not necessarily incompatible with the fractionations documented in the Japan Sea deeply buried and deep-water sediment. For example, transfer of LREE to sediment may be occurring in the uppermost $40 \mathrm{~cm}$ of the Japan Sea sediment, as observed in the estuaries; we would not, however, be able to observe these shallow fractionations as our data profiles begin at 3 mbsf.

We further test the hypothesis of LREE (except Ce) transfer from sediment to interstitial water and assess the budget of Ce in the Japan Sea by combining the water column $\mathrm{Ce} / \mathrm{Ce} *$ profile of Masuzawa and Koyama (1989), located 50-100 km north of Site 794 (Fig. 1), and the downhole $\mathrm{Ce} / \mathrm{Ce}^{*}$ profile to $\sim 300 \mathrm{mbsf}$ at Site 794 (Fig. 6). In order to track the behavior of Ce with respect to its neighboring LREEs and average shale, in addition to $\mathrm{Ce} / \mathrm{Ce}$ * we use the calculated $\mathrm{Ce}_{\text {excess }}=\mathrm{Ce}_{\mathrm{ex}}=\mathrm{Ce}_{\text {sample }}-\left[\mathrm{La}_{\text {sample }} \times\left(\mathrm{Ce}_{\text {shale }} / \mathrm{La}_{\text {shale }}\right)\right]$, which facilitates comparison of percent concentration change in $\mathrm{Ce}$ with respect to $\mathrm{La}$, in units of ppm, and is also a more precise measurement than $\mathrm{Ce} / \mathrm{Ce} *$. A large exchange of $\mathrm{Ce}$, with respect to the other LREEs, occurs within the water column, as nearly $20 \%$ of the $\mathrm{Ce}_{\mathrm{ex}}$ composing the large positive $\mathrm{Ce}$ anomaly on settling particles is recycled during descent through the water column ( $\mathrm{Ce}_{\mathrm{ex}}$ decreases from 16.3 to $\sim 13$ ppm, with $\mathrm{Ce} / \mathrm{Ce} *$ decreasing from $\sim 2.10$ to $\sim 1.28$; Masuzawa and Koyama, 1989). Coastal waters from the southeastern Japan Sea average $\mathrm{Ce} / \mathrm{Ce} * \sim 0.74$ (Tanaka et al., 1990); although these coastal waters are distant from the Site 794 region (Fig. 1), this relative $\mathrm{Ce}$ depletion in water balances the smallest observed enrichment of $\sim 1.28$ in the settling particles (based on an initial $\mathrm{Ce} / \mathrm{Ce}^{*} \sim 1.00$ ). Therefore, in addition to the $20 \% \mathrm{Ce}_{\mathrm{ex}}$ recycled in the water column, there may be a further 13-ppm Ce $e_{\mathrm{ex}}$ that survives water column recycling and is transported to the seafloor environment. This $13 \mathrm{ppm}$ represents the maximum amount of $\mathrm{Ce}$, contributed by the particles, that is recycled at or near the seafloor (Fig. 6; Masuzawa and Koyama, 1989). The surficial sediment $\mathrm{Ce}_{\mathrm{ex}}$ of $\sim 8 \mathrm{ppm}\left(\mathrm{Ce} / \mathrm{Ce}^{*} \sim 1.07\right)$ indicates that $38 \%$ of this maximum $\mathrm{Ce}_{\mathrm{ex}}$ is released to seawater at the seafloor. Thus, because of the great $\mathrm{Ce}$ exchange occurring at the sediment/water interface, there is not a significant source of $\mathrm{Ce}_{\mathrm{ex}}$ to the deeply buried sediment. For example, if at Site 794 the entire $\mathrm{Ce}_{\mathrm{ex}}$ of $8 \mathrm{ppm}$ remaining in the surface sediment $\left(\sim 10 \% \mathrm{Ce}_{\text {total }}\right)$ was released to shallow pore waters and subsequently transferred back to the sediment upon deeper burial, it would generate a positive $\mathrm{Ce}$ anomaly of only $\mathrm{Ce} / \mathrm{Ce}^{*} \sim 1.1$, far less than the observed $\mathrm{Ce} / \mathrm{Ce} *$ of $\sim 1.5$. Therefore, the increases in $\mathrm{Ce} / \mathrm{Ce}^{*}$ with depth are not due to remobilized $\mathrm{Ce}$ from the original input(s). While it is difficult to refine further potential diagenetic mechanisms without deeply buried REE interstitial-water data, the data sets and the Ce budget strongly suggest that the downhole increase in sediment $\mathrm{Ce} / \mathrm{Ce} *$ is a passive response to the behavior of the other LREEs and predict the successive downhole addition of LREEs to deeply buried interstitial waters.

\section{SUMMARY AND CONCLUSIONS}

The most important variation in sedimentary chemical composition throughout the Japan Sea is the increase in $\mathrm{SiO}_{2}$ concentration through Pliocene diatomaceous sequences, which dilutes most of the other major and trace element components by various degrees. This biogenic input is largest at Site 794 (Yamato Basin), moderately developed at Site 797 (Yamato Basin), and of only minor importance at Site 795 (Japan Basin) and potentially reflects basinal contrasts in productivity, with the Yamato Basin in general recording greater biogenic input than the Japan Basin and the easternmost sequence of Site 794 lying beneath the most productive waters of all three sites. There are few large or systematic changes in solid-phase chemistry resulting from the opal-A/opal-CT or opalCT/quartz silica phase transformations. With the exception of certain elements on a site-specific basis, most major and trace element concentrations are controlled by the aluminosilicate fraction of the sediment. The increasing amount of diagenetic phases with depth commonly results in greater concentrations of $\mathrm{SiO}_{2}, \mathrm{CaO}$, and $\mathrm{MnO}$, due to their respective affiliation(s) with diagenetic silica phases and manganese carbonate nodules and stringers.

$\Sigma$ REE concentrations in the Japan Sea are strongly dependent upon the paleoceanographic position of a given site with respect to terrigenous and biogenic sources. $\Sigma$ REE values at Site 794 are strongly diluted by the biogenic component through Unit II and Unit III, and in general correspond well to aluminosilicate chemical indices. Eu/Eu* values at Site 794 reach a maximum through the diatomaceous sequence as well, which most likely reflects a relative Eu enrichment of the siliceous component or may suggest the slight incorporation of a detrital feldspar phase. $\Sigma$ REE at Site 795 also is strongly affiliated with aluminosilicate phases yet is diluted only slightly by siliceous input. At Site 797, also in the Yamato Basin, REE does not correspond well with aluminosilicate indices, is correlated moderately to siliceous input, and appears sporadically and locally influenced by detrital heavy minerals from the nearby rifted continental fragment composing the Yamato Rise.

$\mathrm{Ce} / \mathrm{Ce} *$ profiles at all three sites increase essentially monotonically with depth (except below 400 mbsf at Site 794) and record progressive diagenetic LREE relative fractionation. The observed $\mathrm{Ce} / \mathrm{Ce}$ * increases are not responding to changes in the paleoceanographic oxygenation state of the overlying water, as there are no independent geologic, stratigraphic, paleontologic, or additional chemical data to suggest the existence of a monotonic and progressive oxygenation of the Japan Sea. Ce/Ce* correlates better with depth than with age at the two Yamato Basin sites.

Preliminary calculations suggest that at Sites 794 and 797 the transfer of LREEs (with the exception of $\mathrm{Ce}$ ) from sediment to interstitial water may account for all of the observed relative $\mathrm{Ce}$ increase. Therefore, the observed downhole increase in $\mathrm{Ce} / \mathrm{Ce} *$ may be a passive response to diagenetic behavior of the non-Ce LREEs. At Site 795, the overall lack of correlation between $\mathrm{Ce} / \mathrm{Ce} *$ and $\mathrm{La}_{\mathrm{n}} / \mathrm{Yb}_{\mathrm{n}}$ suggests that other process are occurring which mask the diagenetic behavior of all LREEs. First-order calculations of the relative Ce budget suggest that $\sim 20 \%$ of the $\mathrm{Ce}_{\text {excess }}$ adsorbed by 
settling particles is recycled within the water column and that an additional $\sim 38 \%$ is recycled at or near the sediment/water interface (data from Masuzawa and Koyama, 1989). Thus, because the remaining $45 \% \mathrm{Ce}_{\mathrm{ex}}$ translates to 8-ppm $\mathrm{Ce}_{\mathrm{ex}}$ and equals only $\sim 10 \% \mathrm{Ce}_{\text {total }}$, there is not a significant source of $\mathrm{Ce}$ to the deeply buried sediment, further suggesting that the downhole increase in $\mathrm{Ce} / \mathrm{Ce} *$ is a passive response to behavior of the other LREEs. The REE chemistry of the Japan Sea sediment therefore predicts the successive downhole addition of LREEs to interstitial waters with deep burial.

\section{ACKNOWLEDGMENTS}

We thank Dr. E. H. De Carlo and an anonymous reviewer for their comments and Dr. D. Nobes (U. of Waterloo, Canada) for providing the physical-property residue samples. We thank the most helpful and professional technical staff of the ODP, and particularly the Leg 127 shipboard personnel of MaryAnn Cusimano and Luis Alvarez (chemistry technicians), Matt Mefferd (assistant lab officer), Barry Weber (electronic technician), and Don Sims (marine technician, X-ray lab). Larry Bernstein and Burney Hamlin assisted in keeping the shipboard chemistry lab running smoothly. We also thank the Leg 127 co-chief scientists (Drs. K. Pisciotto and K. Tamaki) and ODP staff scientist (Dr. J. A. Allan) and curatorial representative (Peggy Myre Murray) for accommodating last-minute sample requests and for providing essential shipboard support. Additionally, we thank G. Hunt and J. Bazan at LLNL for assistance with the ICP-MS, as well as G. Anderson and $\mathrm{G}$. Phelps for the sample preparation at University of California at Berkeley. This work was partially supported by the Institute for Geophysics and Planetary Physics at Lawrence Livermore National Laboratory Grant \# 90-41 and performed under the auspices of the U.S. Department of Energy by Lawrence Livermore National Laboratory under Contract W-7405-Eng-48. The work was performed while R. W. Murray held a shore-based JOI/USSAC Ocean Drilling Fellowship, and funded additionally by a JOI/USSAC Cruise Science Support grant to R. W. Murray.

This manuscript contains material that is excerpted for a shorter manuscript, emphasizing REE behavior, published by Geochimica et Cosmochimica Acta. Both manuscripts were submitted simultaneously in accordance with ODP policy regarding dual submittal of ODP results, and with full knowledge of the executive editor of Geochimica. We thank R. L. Cullers, C. R. German, R. L. Korotev, and R. A. Schmitt for their reviews of the Geochimica paper, many of which were incorporated in this longer ODP contribution.

\section{REFERENCES}

Boles, J. R., and Franks, S. G., 1979. Clay diagenesis in Wilcox Sandstones of southwest Texas: implications of smectite diagenesis on sandstone cementation. J. Sediment. Petrol., 49:55-70.

Condie, K. C., 1991. Another look at rare earth elements in shales. Geochim. Cosmochim. Acta, 55:2527-2531.

Donnelly, T. W., and Merrill, L., 1977. The scavenging of magnesium and other chemical species by biogenic opal in deep-sea sediments. Chem. Geol., 19:167-186.

Dymek, R. F., and Gromet, L. P., 1984. Nature and origin of orthopyroxene megacrysts from the St.-Urbain anorthosite massif, Quebec. Can. Mineral., 22:297-326.
Elderfield, H., 1988. The oceanic chemistry of the rare-earth elements. Philos. Trans. R. Soc. London A, 325:105-126.

Fagel, N., Andre, L., Chamley, H., Debrabant, P., and Jolivet, L., 1991. Clay sedimentation in a back-arc environment: the Japan Sea, ODP Leg 127. Terra, 3:283. (Abstract)

Fleet, A. J., 1984. Aqueous and sedimentary geochemistry of the rare earth elements. In Henderson, P. (Ed.), Rare Earth Element Geochemistry: New York (Elsevier), 343-373.

German, C. R., and Elderfield, H., 1990a. Application of the Ce anomaly as a paleoredox indicator: the ground rules. Paleoceanography, 5:823-833.

, 1990b. Rare earth elements in the NW Indian Ocean. Geochim. Cosmochim. Acta, 54:1929-1940.

Gromet, L. P., Dymek, R. F., Haskin, L. A., and Korotev, R. L., 1984. The "North American Shale Composite": its compilation, major and trace element characteristics. Geochim. Cosmochim. Acta, 48:2469-2482.

Haskin, M. A., and Haskin, L. A., 1966. Rare earths in European shales, a redetermination. Science, 154:507-509.

Hower, J., Eslinger, E. V., Hower, M. E., and Perry, E. A., 1976. Mechanism of burial metamorphism of argillaceous sediment: 1. Mineralogical and chemical evidence. Geol. Soc. Am. Bull., 87:725-737.

Jarvis, I., and Jarvis, K. E., 1985. Rare-earth element geochemistry of standard sediments: a study using inductively coupled plama spectrometry. Chem. Geol., 53:335-344.

Liu, Y.-G., Miah, M.R.U., and Schmitt, R. A., 1988. Cerium: a chemical tracer for paleo-oceanic redox conditions. Geochim. Cosmochim. Acta, 52:1361-1371.

Masuzawa, T., and Koyama, M., 1989. Settling particles with positive Ce anomalies from the Japan Sea. Geophys. Res. Lett., 16:503-506.

McLennan, S. M., 1989. Rare earth elements in sedimentary rocks: influence of provenance and sedimentary processes. In Lipin, B. R., and McKay, G. A. (Eds.), Geochemistry and Mineralogy of the Rare Earth Elements. Rev. Mineral., 21:169-200.

Murray, R. W., Buchholtz ten Brink, M. R., Gerlach, D. C., Russ, G. P., III, and Jones, D. L., 1991. Rare earth, major and trace elements in chert from the Franciscan Complex and Monterey Group, California: assessing REE sources to fine-grained marine sediments. Geochim. Cosmochim. Acta, 55:1875-1895.

Ruhlin, D. E., and Owen, R. M., 1986. The rare earth element geochemistry of hydrothermal sediments from the East Pacific Rise: examination of a seawater scavenging mechanism. Geochim. Cosmochim. Acta, 50:393-400.

Sholkovitz, E. R., 1988. Rare earth elements in the sediments of the North Atlantic Ocean, Amazon Delta, and East China Sea: reinterpretation of terrigenous input patterns to the oceans. Am. J. Science, 288:236-281.

, 1990. Rare earth elements in marine sediments and geochemical standards. Chem. Geol., 88:333-347.

Sholkovitz, E. R., Piepgras, D. J., and Jacobsen, S. B., 1989. The pore-water chemistry of rare earth elements in Buzzards Bay sediments. Geochim. Cosmochim. Acta, 53:2847-2856.

Tamaki, K., Pisciotto, K., Allan, J., et al., 1990. Proc. ODP, Init. Repts., 127: College Station, TX (Ocean Drilling Program).

Tanaka, M., Shimuzu, H., and Masuda, A., 1990. Features of the heavy rare-earth elements in seawater. Geochem. J., 24:39-46.

Taylor, S. R., and McLennan, S. M., 1985. The Continental Crust: Its Composition and Evolution: Oxford (Blackwell Scientific).

Date of initial receipt: 18 March 1991

Date of acceptance: 29 August 1991

Ms 127/128B-176 